

\title{
PELAGIC PREDATORS
}

\section{Peter G. Ryan and Marthán N. Bester}

Given the general paucity of land-masses in the Southern Ocean, sub-Antarctic islands are characterised by vast populations of marine organisms that require terrestrial breeding and moulting sites - seabirds and seals. The islands are important for the conservation of these species, because when seabirds and seals breed and, in some species, moult, they are forced to aggregate in high densities at relatively few sites where they are vulnerable to disturbance, habitat modification and especially the threat of introduced predators and pathogens. At the same time, the vast numbers of breeding seabirds and seals influence terrestrial ecosystems and the near-shore marine environment around the islands by importing substantial amounts of nutrients and energy from more distant pelagic waters. This subject is covered in more detail by Smith \& Froneman (2008), but penguins alone are estimated to import more than 30000 tons of guano, feathers, carcasses and eggs to Marion Island each year (Burger et al. 1978; Siegfried et al. 1978; Williams \& Berruti 1978). Seabirds and seals also influence the islands' terrestrial ecosystems through trampling, erosion and transport of propagules (Cooper \& Brown 1990). Other pelagic predators, such as cetaceans, are not constrained to visit land to reproduce, yet also may aggregate in the waters around the islands because of locally enhanced production caused by oceanographic features around the island (McQuaid \& Froneman 2008) and nutrient inputs from the land-based predators, or in the

\footnotetext{
S.L. Chown \& P.W. Froneman (eds.) The Prince Edward Islands $\bullet$ Land-Sea Interactions in a Changing Ecosystem, 121-164
} 
case of large predators, simply be attracted by concentrations of their seal and seabird prey. This chapter briefly introduces the pelagic predators occurring at the Prince Edward Islands, reports their spatial and temporal distribution both at sea and on the islands, and considers how their populations respond to environmental variability in the surrounding oceanic environment and to human impacts, both at sea and on land.

\section{I The abundance, distribution and phenology of pelagic predators ashore}

\subsection{Pinnipeds}

Three species of seals breed at the Prince Edward Islands: Southern Elephant Seal Mirounga leonina (Phocidae), and sub-Antarctic Arctocephalus tropicalis and Antarctic Fur Seals A. gazella (Otariidae). All three species were exploited historically, resulting in severe population decreases within a few years in the early 1800s (Cooper \& Headland 1991), with hunting continuing sporadically until 1931 (Kerley 1987). Populations of fur seals possibly have recovered to pre-exploitation levels (Bester et al. 2003; Hofmeyr et al. 2006). Annual pup production of Elephant Seals at the islands is $c .560$ (Table 6.1), which suggests an overall population of $c .1800$ individuals older than pups (Pistorius et al. 2004; Bester \& Hofmeyr 2005). The pup production is only $0.26 \%$ of the world total (SCAR EGS 2004). Fur seal pup counts at Marion Island were c.16 000 sub-Antarctic Fur Seals and 760 Antarctic Fur Seals in 2003/04 (Hofmeyr et al. 2006). Together with Prince Edward Island (Bester et al. 2003), this suggests a total population of c.150 000 sub-Antarctic Fur Seals and 5600 Antarctic Fur Seals (Hofmeyr et al. 2006; Table 6.1), 33\% and 0.2\% of the world populations, respectively (SCAR EGS 2004). The biomass of seals breeding at the islands is approximately 7500 tons, with some 2500 tons of Elephant Seals and 5000 tons of fur seals. Marion Island supports the majority of seals (58\% of biomass overall), mainly due to the greater numbers of Elephant Seals $(72 \%$ of the population; Table 6.1).

Seals cause significant erosion and trampling of coastal habitats (Hall \& Williams 1981) and import nutrients and energy to terrestrial ecosystems through faeces, placentas, corpses (mainly pups) and moult skin and hair (Panagis 1984). Elephant Seals mainly visit sheltered beaches along the eastern coast of both Marion and Prince Edward Islands (Condy 1978a; Bester \& Hofmeyr 2005), and have their peak impact during spring and summer (Panagis 1984). Much of the material from breeding Elephant Seals is likely washed out to sea, but during moult it is largely retained, because of the formation of characteristic hummocky and boggy areas at traditional moult sites (Hall \& Williams 1981). Fur seals are more agile than Elephant Seals, able to land at more exposed beaches and to venture further inland. On Marion Island, sub-Antarctic Fur Seals preferentially visit beaches composed of large jumbled boulders, exposed to the prevailing westerlies (Condy 1978b), possibly for thermoregulatory reasons (Bester 1982; Bester \& Roussouw 1994), whereas on Prince Edward 
Island breeding sites occur primarily in the eastern part of the island (Bester et al. 2003), possibly because of the paucity and extremely exposed nature of west-facing beaches (Condy 1978b; Kerley 1983a). Antarctic Fur Seals on both islands prefer flat pebble beaches with adjacent open vegetated areas on sheltered coasts (Condy 1978b; Kerley 1984; Bester et al. 2003). Breeding aggregations of the two fur seal species are almost entirely allopatric (Bester et al. 2003; Hofmeyr et al. 2006). Adult and subadult male Antarctic fur seals kill King Penguins Aptenodytes patagonicus and, to a lesser extent, Macaroni Penguins Eudyptes chrysolophus, mainly during August to October at Goodhope Bay, Marion Island (Hofmeyr \& Bester 1993; Mammal Research Institute, unpublished data). It is possible that the decline in the small King Penguin colony at Goodhope Bay (Van Heezik et al. 1995; Crawford et al. 2003a) is due to seal predation.

Table 6.1 Body mass and approximate numbers of seals breeding annually at the Prince Edward Islands. Adapted from Payne (1979), Laws (1993), Bester \& Van Jaarsveld (1994), McCafferty et al. (1998), Pistorius et al. (1999b), Kirkman et al. (2002), Bester et al. (2003), McMahon et al. (2003), Bester \& Hofmeyr (2005), Hofmeyr et al. (2006) and M.N. Bester unpublished data.

\begin{tabular}{|c|c|c|c|c|}
\hline Species & & $\begin{array}{l}\text { Mean } \\
\text { mass (kg) }\end{array}$ & $\begin{array}{l}\text { Marion } \\
\text { Island }\end{array}$ & $\begin{array}{l}\text { Prince } \\
\text { Edward }\end{array}$ \\
\hline \multirow{4}{*}{$\begin{array}{l}\text { Southern Elephant Seal } \\
\text { Mirounga leonina }\end{array}$} & Total population & & $1764^{a}$ & $540^{\mathrm{b}}$ \\
\hline & Adult males & $3000-4000$ & & \\
\hline & Adult females & $400-900$ & & \\
\hline & Pups (at weaning) & 120.6 & $434^{\mathrm{a}}$ & $130^{\mathrm{b}}$ \\
\hline \multirow{8}{*}{$\begin{array}{l}\text { Sub-Antarctic Fur Seal } \\
\text { Arctocephalus tropicalis }\end{array}$} & Total population & & $77000^{c}$ & $72000^{d}$ \\
\hline & Adult males & 88.3 & & \\
\hline & Adult females & 34.1 & & \\
\hline & Immature males & 26.4 & & \\
\hline & Immature females & 12.8 & & \\
\hline & \multirow{3}{*}{$\begin{array}{l}\text { Pups (300 d mean age) } \\
\text { males } \\
\text { females }\end{array}$} & & $16045^{c}$ & $15000^{d}$ \\
\hline & & $13.4-15.7$ & & \\
\hline & & $11.4-15.1$ & & \\
\hline \multirow{8}{*}{$\begin{array}{l}\text { Antarctic Fur Seal } \\
\text { Arctocephalus gazella }\end{array}$} & Total population & & $3600^{c}$ & $2000^{d}$ \\
\hline & Adult males & 125.2 & & \\
\hline & Adult females & 37.9 & & \\
\hline & Immature males & 37.8 & & \\
\hline & Immature females & 16.0 & & \\
\hline & \multirow{3}{*}{$\begin{array}{l}\text { Pups (110 d mean age) } \\
\text { males } \\
\text { females }\end{array}$} & & $759^{c}$ & $400^{d}$ \\
\hline & & $11.1-14.5$ & & \\
\hline & & $10.2-12.2$ & & \\
\hline
\end{tabular}


Southern Elephant Seals come to land to breed, moult and winter. The duration and timing of the different haul-outs depend on an animal's age, sex and social status, with a high degree of synchronization and consistent timing across years (Condy 1979; Kirkman et al. 2001, 2003, 2004). The breeding season begins with bulls hauling out in mid-August to establish territories, and pregnant cows follow early in September, aggregating in harems (Condy 1979). Harems reach their maximum size in mid-October, with peak numbers of pups about one week later (Condy 1979; Wilkinson 1992). After parturition and three weeks of lactation, mated females leave. The moult haul-out is obligatory to all seals except pups of the year, which commence moulting while still suckling. Timing of moult depends on age and sex, with yearlings of both sexes hauling out first from mid-November, remaining until late January. Subadults of both sexes and adult females moult from mid-December to midMarch, and adult males from late December to mid-April (Condy 1979). The third and least understood haul-out is the resting or winter haul-out (Hofmeyr 2000; Kirkman et al. 2001). It involves mostly juveniles of both sexes, with occasional appearances by mainly adult males (Kirkman et al. 2001).

Both fur seals have similar annual cycles, differing mainly in the duration of lactation, which lasts four months in Antarctic Fur Seals and 10 months in subAntarctic Fur Seals (Kerley 1985). After giving birth primarily in December (median birthdates of 6 December and 17 December for Antarctic and subAntarctic Fur Seals, respectively; Kerley 1985), they care for the single pup by alternating foraging trips at sea where they feed, and visits ashore where they suckle their pup (Bester \& Bartlett 1990). There is a second peak in numbers ashore during April, probably related to moulting (Kerley 1983a).

\subsubsection{Penguins}

Four species of penguins (Spheniscidae) breed at the Prince Edward Islands: King, Gentoo Pygoscelis papua, Macaroni and Southern Rockhopper Eudyptes chrysocome filholi. At least King Penguins were exploited historically, but they have not been hunted since the 1930s (Cooper \& Headland 1991), and the numbers taken were such that current populations probably show little if any impact of past exploitation (Crawford et al. 2003a). Current populations are summarised in Table 6.2. The islands support some $13 \%$ of King Penguins worldwide, $4 \%$ of Macaroni Penguins and only $0.5 \%$ of Gentoo Penguins (Woehler 1993; Williams 1995; Crawford \& Cooper 2003). The population of Southern Rockhopper Penguins is about $5 \%$ of the world population (and 17\% of the eastern race filholi), but this is affected by the rapid decreases observed at many colonies, including Marion Island (Crawford et al. 2003b; BirdLife International 2004a). Penguins dominate the avian biomass at the islands, comprising some $97 \%$ of the biomass of breeding adults at Marion Island (9 200 tons) and 60\% of the biomass at Prince Edward Island (750 tons). Their combined biomass exceeds that of seals breeding at the islands. Penguins also contribute most of the material imported to Marion Island by seabirds, although much of it is 
deposited close to the coast on soil-free areas, where large amounts are washed into the sea and is thus more significant to enriching near-shore waters (Cooper \& Brown 1990; Perissinotto \& Duncombe Rae 1990).

Table 6.2 Body mass and approximate numbers of adult seabirds breeding annually at the Prince Edward Islands. Adapted from Cooper \& Brown (1990), Marchant \& Higgins (1990), Crawford et al. (2003a, b, c), Ryan et al. (2003a).

\begin{tabular}{|l|r|r|r|}
\hline \multicolumn{1}{|c|}{ Species } & Mass $(\mathrm{kg})$ & Marion & P. Edward \\
\hline King Penguin Aptenodytes patagonicus & 12.0 & 440000 & 6000 \\
\hline Gentoo Penguin Pygoscelis papua & 6.0 & 1800 & 1200 \\
\hline Macaroni Penguin Eudyptes chrysolophus & 4.6 & 720000 & 30000 \\
\hline Rockhopper Penguin Eudyptes chrysocome & 2.7 & 134000 & 90000 \\
\hline Wandering Albatross Diomedea exulans & 9.0 & 3600 & 3700 \\
\hline Grey-headed Albatross Thalassarche chrysostoma & 3.7 & 15800 & 6000 \\
\hline Yellow-nosed Albatross Thalassarche carteri & 2.6 & 0 & 15000 \\
\hline Light-mantled Sooty Albatross Phoebetria palpebrata & 2.8 & 400 & 300 \\
\hline Dark-mantled Sooty Albatross Phoebetria fusca & 2.5 & 2400 & 2000 \\
\hline Southern Giant Petrel Macronectes giganteus & 4.5 & 3500 & 2000 \\
\hline Northern Giant Petrel Macronectes halli & 4.0 & 700 & 600 \\
\hline Fairy Prion Pachyptila turtur & 0.14 & 2000 & 2000 \\
\hline Salvin's Prion Pachyptila salvini & 0.17 & 200000 & 500000 \\
\hline Blue Petrel Halobaena caerulea & 0.20 & 100000 & 200000 \\
\hline Great-winged Petrel Pterodroma macroptera & 0.59 & 20000 & 20000 \\
\hline Soft-plumaged Petrel Pterodroma mollis & 0.31 & 10000 & 20000 \\
\hline Kerguelen Petrel Lugensa brevirostris & 0.35 & 20000 & 20000 \\
\hline Grey Petrel Procellaria cinerea & 1.0 & 2000 & 10000 \\
\hline White-chinned Petrel Procellaria aequinoctialis & 1.3 & 20000 & 10000 \\
\hline Grey-backed Storm Petrel Garrodia nereis & 0.03 & $?$ & 2000 \\
\hline Black-bellied Storm Petrel Fregetta tropica & 0.05 & $?$ & 10000 \\
\hline South Georgian Diving Petrel Pelecanoides georgicus & 0.11 & 1000 & 10000 \\
\hline Gommon Diving Petrel Pelecanoides urinatrix & 0.15 & $?$ & 20000 \\
\hline Crozet Shag Phalacrocorax melanogenis & 2.2 & 540 & 100 \\
\hline Sub-Antarctic Skua Catharacta antarctica & 1.6 & 1200 & 500 \\
\hline Kelp Gull Larus dominicanus & 1.0 & 200 & 60 \\
\hline Antarctic Tern Sterna vittata & 0.14 & 50 & 10 \\
\hline Kerguelen Tern Sterna virgata & 0.12 & 100 & 10 \\
\hline
\end{tabular}


In addition to importing nutrients and energy, penguins are significant local agents of erosion. Macaroni and King Penguins breed in dense colonies, which typically kill all vegetation and erode peat to bedrock (Hall \& Williams 1981). However, both species are spatially limited, with King Penguins breeding in up to 15 colonies on Marion Island and three on Prince Edward Island, all at sheltered sites with gently-shelving landing beaches (Hall \& Williams 1981; Van Heezik et al. 1995; Ryan et al. 2003a). Macaroni Penguins are less constrained by a need for sheltered landing sites, breeding in more than 50 colonies at Marion Island and seven at Prince Edward Island, but some 80\% breed at two sites on the east coast of Marion Island, at Bullard and Kildalkey (Crawford et al. 2003c; Ryan et al. 2003a), where they have removed some $3 \times 10^{5} \mathrm{~m}^{3}$ of peat (Hall \& Williams 1981). By comparison, more agile Rockhopper Penguins occur around the coasts of both islands, breeding along all but the most sheer of cliffs (Crawford et al. 2003b; Ryan et al. 2003a). They also penetrate further inland, at least locally, but do not venture as far from the coast as the small numbers of Gentoo Penguins breeding at both islands (Adams \& Wilson 1987; Grawford et al. 2003d; Ryan et al. 2003a).

Apart from King Penguins, which lay a single egg, all species lay two eggs, but only Gentoo Penguins very occasionally raise two chicks (Williams 1995). In terms of phenology, King Penguins have a complex breeding system, laying eggs from mid-November to March (Williams 1995). Chicks must grow rapidly and store sufficient body reserves by June in order to survive 3-4 months with little or no food (Van Heezik et al. 1993). Only chicks from eggs laid early in the summer (hatching before 7 February) typically survive to fledge the following summer (Van Heezik et al. 1993). However, this forces successful breeders to lay eggs late the following summer, almost invariably causing their breeding attempts to fail, and many birds elect to skip breeding in successive years (Van Heezik et al. 1994). Macaroni and Rockhopper Penguins both breed in summer. Macaroni Penguins occupy colonies slightly earlier (from early October), fledging chicks around the end of February (Crawford et al. 2003c), whereas Rockhoppers return to the island in mid-late October, fledge chicks in March (Cooper \& Brown 1990). Gentoo Penguins are inshore feeders that remain at the islands year round and have a protracted breeding season. Egg laying takes place from June-November, with chicks present as late as February (Cooper \& Brown 1990). They differ from other penguins at the islands, in that they may lay replacement clutches if a breeding attempt fails (Williams 1980).

Penguins are unusual among seabirds at the Prince Edward Islands in also having to return to land to moult. They replace all their feathers in a simultaneous moult lasting 15-30 days, during which time they remain ashore, fasting (Brown 1986; Williams 1995). This is energetically expensive, and requires pre-moult fattening and post-moult recovery periods lasting several weeks. Adult King Penguins moult in summer, from October-February (Van Heezik et al. 1995), with early birds having failed in their breeding attempt the previous year (Weimerskirch et al. 1992). Adult Macaroni and Rockhopper 
penguins return to the island to moult a few weeks after they finish raising their chicks; Macaroni Penguins moulting in March-April, and Rockhopper Penguins in April-May (Cooper \& Brown 1990). Adult Gentoo Penguins also moult after breeding, mainly during December-February (Williams 1995). Immature penguins also have to return to land to moult on a roughly annual basis, usually returning earlier than adults because they are not constrained to moult after breeding (Williams 1995).

\subsubsection{Albatrosses}

Five species of albatrosses (Diomedeidae) breed at the Prince Edward Islands: Wandering Albatross Diomedea exulans, Grey-headed Albatross Thalassarche chrysostoma, and Light-mantled Phoebetria palpebrata and Dark-mantled Phoebetria fusca Sooty Albatrosses breed at both islands, whereas Indian Yellow-nosed Albatrosses Thalassarche carteri only breed at Prince Edward Island. Annual breeding populations are summarised in Table 6.2, but with the exception of Yellow-nosed Albatrosses, most pairs breed only every second year if they successfully raise a chick (Brooke 2004), and thus the actual breeding population is up to $80 \%$ larger than the numbers given in Table 6.2. The islands support some $44 \%$ of all Wandering Albatrosses, 10\% of Grey-headed Albatrosses and 21\% of Indian Yellow-nosed Albatrosses (Tickell 2000; Crawford \& Cooper 2003). Numbers of sooty albatrosses are poorly known globally, but the islands support perhaps 10\% of Dark-mantled and 2\% of Light-mantled Sooty Albatrosses (Tickell 2000; Crawford \& Cooper 2003). Annual breeding biomass is $c .100$ tons on each of Marion and Prince Edward Islands.

All species lay a single egg, which is not replaced if the breeding attempt fails (Warham 1990). Wandering Albatrosses breed in loose colonies on level coastal plains and are scattered around the islands, reaching peak densities in Albatross Valley on the north-east coast of Prince Edward Island (c. 22 nests. $\mathrm{ha}^{-1}$ ); average density in colonies at Marion Island is $c .5$ nests.ha $^{-1}$ (Underhill et al. 2003). Their nests are large mounds of vegetation and peat, plucked from the area immediately surrounding each, creating a localised source of disturbance and nutrient input. The other four albatrosses all breed on cliffs, with sooty albatrosses scattered singly or in small colonies around the islands and Grey-headed Albatrosses and Yellow-nosed Albatrosses in large, dense colonies. Grey-headed Albatrosses breed on cliffs along the south coast of Marion Island and in a mixed colony with Yellow-nose Albatrosses on the north-east coast of Prince Edward Island. The nests of all four cliff-nesting species are tall cones of muddy-peat, built by the birds, also creating point sources of disturbance and nutrient input. The dense, cliff-side colonies of Thalassarche albatrosses also promote local slump erosion (Hall \& Williams 1981).

The four smaller albatrosses all breed in summer, returning to colonies from August to late September and fledging chicks from March (Yellow-nosed Albatross) to May (sooty albatrosses). The larger Wandering Albatross lays in mid-summer, eggs hatch in March, and chicks fledge from December-February 
(Cooper \& Brown 1990; Marchant \& Higgins 1990). All species have delayed onset of maturity, first breeding at 10-12 years old on average (Nel et al. 2003; Brooke 2004), with onset of breeding linked to acquisition of high body mass (Weimerskirch 1992).

\subsubsection{Petrels}

At least 14 species of petrels (Procellariidae) breed at the Prince Edward Islands, and with the exception of the two species of giant petrels Macronectes spp., all breed in burrows, commuting mainly at night to reduce the risk of predation by sub-Antarctic Skuas Catharacta antarctica (Lariidae). As a result, their populations are much less well known than are those of the surface-nesting species. The population estimates presented in Table 6.2 are conservative, and the proportions of global populations breeding at the islands are not known, other than for the two species of giant petrels (Northern Macronectes halli 5\% and Southern Macronectes giganteus 9\%; Crawford \& Cooper 2003). The islands are important sites for Salvin's Prions Pachyptila salvini, which breed in vast numbers and are confined to sub-Antarctic islands in the Indian Ocean sector of the Southern Ocean. Populations of many burrow-nesting species at Marion Island were severely depressed by predation by feral cats Felis catus (Van Aarde 1980), now removed from the island (Bester et al. 2002), leading to the local extinction of some species (Cooper \& Brown 1990). The total breeding biomass is $c .300$ tons, with probably slightly more on smaller Prince Edward Island than on Marion Island.

All species lay a single egg, which is not replaced if the breeding attempt fails (Warham 1990). Giant petrel nests are low mounds of vegetation, similar to those of Wandering Albatrosses, with Northern Giant Petrels breeding singly or in loose groups against sheltering rocks, whereas Southern Giant Petrels breed colonially in more open areas (Cooper et al. 2001). Both are important for transporting material further inland from coastal seal and penguin colonies (Hunter 1985). The burrow-nesting species breed singly, in loose colonies or, in the case of Blue Petrels Halobaena caerulea, in dense colonies. Their burrowing activity removes up to $1 \mathrm{~m}^{3}$ of peat and lithosol per nest, with an average of around $0.2 \mathrm{~m}^{3}$ (Hall \& Williams 1981; Boelhouwers et al. 2008). Given a population of at least 500000 pairs, they are highly significant agents of erosion (Hall \& Williams 1981). Most breeding occurs on the coastal plain and lower slopes of the islands (Hunter 1990), but extends to the highest parts of Prince Edward Island (Ryan et al. 2003a). Because of their wide spatial range and deposition of guano and other material underground, they are extremely important sources of nutrients for terrestrial vegetation (Cooper \& Brown 1990; Smith \& Froneman 2008).

Most species breed in summer, but Great-winged Pterodroma macroptera and Grey Procellaria cinerea Petrels breed in winter, laying eggs in May and fledging chicks in September-October (Cooper \& Brown 1990). Like albatrosses, most species spend the non-breeding season at sea, but Blue Petrels return to the 
islands in April-May to clean out burrows and apparently re-establish pair bonds (Cooper \& Brown 1990).

\section{I.5 Other seabirds}

Five other seabird species breed at the Prince Edward Islands: Crozet Shags Phalacrocorax melanogenis (Phalacrocoracidae), and sub-Antarctic Skuas, Kelp Gulls Larus dominicanus, and Antarctic Sterna vittata and Kerguelen Sterna virgata Terns (Laridae). All feed on the island or in coastal waters, and are thus not strictly pelagic predators. They occur in relatively small numbers (Table 6.2), with a total biomass at both islands of $c .4 .5$ tons. However, the islands are important as one of only two archipelagos where Crozet Shags breed $(33 \%$ of world population), and one of only three where Kerguelen Terns breed (3\% of world population; Crawford \& Cooper 2003). All are surface nesters that breed in summer (Cooper \& Brown 1990), although some Crozet Shags at Prince Edward Island occasionally nest in winter (Ryan \& Hunter 1985). As mainly coastal foragers, they lay larger clutches than pelagic-feeding species, usually 2 (1-3) eggs. Crozet Shags breed on cliffs and offshore rocks (Crawford et al. 2003e; Ryan et al. 2003a). Sub-Antarctic Skuas breed throughout Prince Edward Island (Ryan et al. 2003a) and occur widely on the coastal plain at Marion Island, with aggregations around large penguin colonies. They are important in transporting penguin material away from the immediate coastal zone (Hunter 1995), and the islands support $11 \%$ of the world population (Crawford \& Cooper 2003). Kelp Gulls and terns breed at scattered localities along the coast and inland, mainly along the more sheltered eastern coasts (Crawford et al. 2003a; Ryan et al. 2003a).

Apart from seabirds, there is only one breeding bird at the Prince Edward Islands, the Lesser or Black-faced Sheathbill Chionis minor (Chionidae), represented by an endemic subspecies C. m. marionensis. We mention it here because it derives a substantial portion of its food directly or indirectly from the sea. It breeds in summer, when it obtains most of its food from breeding seabirds, either scavenging or stealing food (Burger 1981). Sheathbills are well known for knocking over chicks as parents regurgitate food into their mouths, causing the food to be spilled and thus made available to the sheathbills (Marchant \& Higgins 1993). In winter some scavenge in King Penguin colonies, but others forage along the coast or hunt for insects inland (Burger 1982; Huyser et al. 2000). The Lesser Sheathbill is confined to sub-Antarctic islands in the southern Indian Ocean. The Prince Edward Island population is some 1400 pairs, around 20\% of the world total (Marchant \& Higgins 1993). There is some evidence that numbers have decreased at Marion Island, possibly due to competition with introduced House Mice Mus musculus for invertebrate prey in winter (Huyser et al. 2000). 


\subsection{Diets and foraging methods of pelagic predators}

Virtually all studies of the diets of pelagic predators have taken place on animals at the breeding islands (Table 6.3). Analysis of regurgitated pellets and scats overestimates the contributions of prey with hard, indigestible remains such as squid beaks and otoliths (Cooper \& Brown 1990). Development of non-destructive stomach flushing techniques for seabirds (Wilson 1984; Ryan \& Jackson 1986) revolutionised diet studies, although rapidly-digested, softbodied prey, such as tunicates, salps and jellyfish, probably are overlooked in most species (Duffy \& Jackson 1986). However, information is largely confined to the chick-rearing period. Seals are more problematic, because they do not bring food back to the islands to feed their young, but scat analysis provides some information for fur seals. As a result, knowledge of predator diets ranges from fairly well known for some breeding seabirds to poorly known for elephant seals and non-breeding seabirds (Table 6.3). Stable isotope analyses provide a way to infer diet and feeding areas at other times of the year (e.g. Cherel et al. 2005; Bearhop et al. 2006; Hilton et al. 2006), and can also indicate where moult takes place in birds (Cherel et al. 2000), but there have been no studies conducted to date at the Prince Edward Islands.

Selectivity of predator diets are in part determined by their foraging methods. Southern Ocean seabirds use a diversity of foraging methods (Harper et al. 1985), with the major factors affecting diet being body size (which determines the size range of prey; Ridoux 1994) and diving ability (which to a large extent determines the extent to which species can afford to be selective in their diet). Diving ability is, in turn, traded off against cost of flight, due to the buoyancy costs of having large wings (Kuroda 1954; Wilson et al. 1992). In general, pursuit divers tend to be more selective predators, whereas species confined to feeding at the surface are generalist scavengers (Ryan 1987a; Ridoux 1994). Knowledge of foraging behaviour of pelagic predators has been revolutionised over the last two decades due to the development of miniature data loggers that can be attached to the animals (Boyd 1997; Wilson et al. 2002).

\subsubsection{Pinnipeds}

Seals are accomplished divers. Adult Southern Elephant Seals dive to depths of up to $1500 \mathrm{~m}$, with adult females primarily diving to $300-400 \mathrm{~m}$ at night and 500-600 $\mathrm{m}$ during the day (Jonker \& Bester 1994). They spend virtually no time foraging at or near the surface, and those from Marion Island were not recorded to perform benthic dives (Jonker \& Bester 1998). Their diet at the Prince Edward Islands is virtually unknown, with only the squid Kondakovia longimana found in one stomach (M.N. Bester, unpublished data). Elsewhere, Southern Elephant Seals prey upon a range of fish and squid species (Laws 1956), with composition differing between sites, season and sex (Slip 1995; Daneri et al. 2000; Daneri \& Carlini 2002; Van den Hoff et al. 2003). 


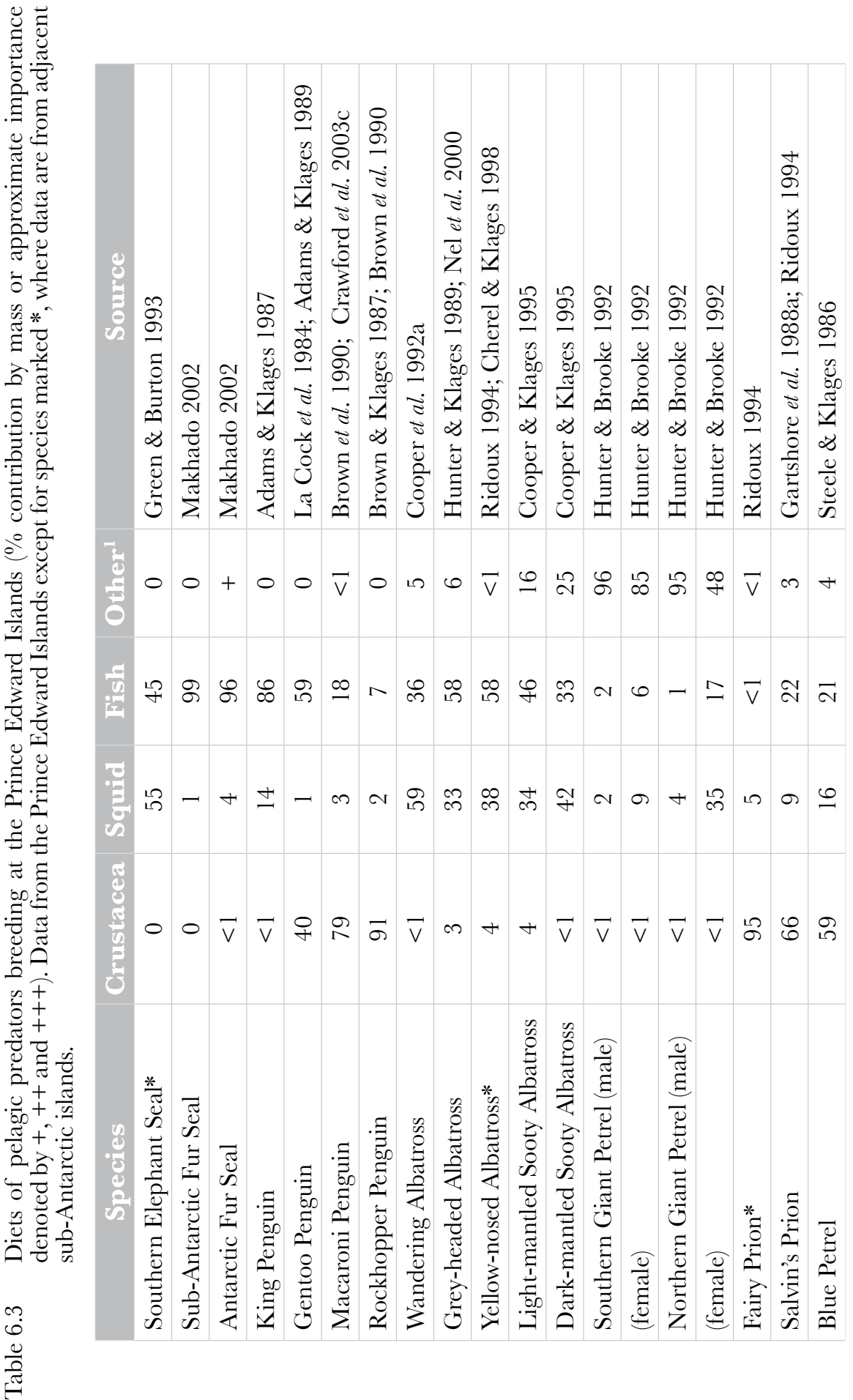




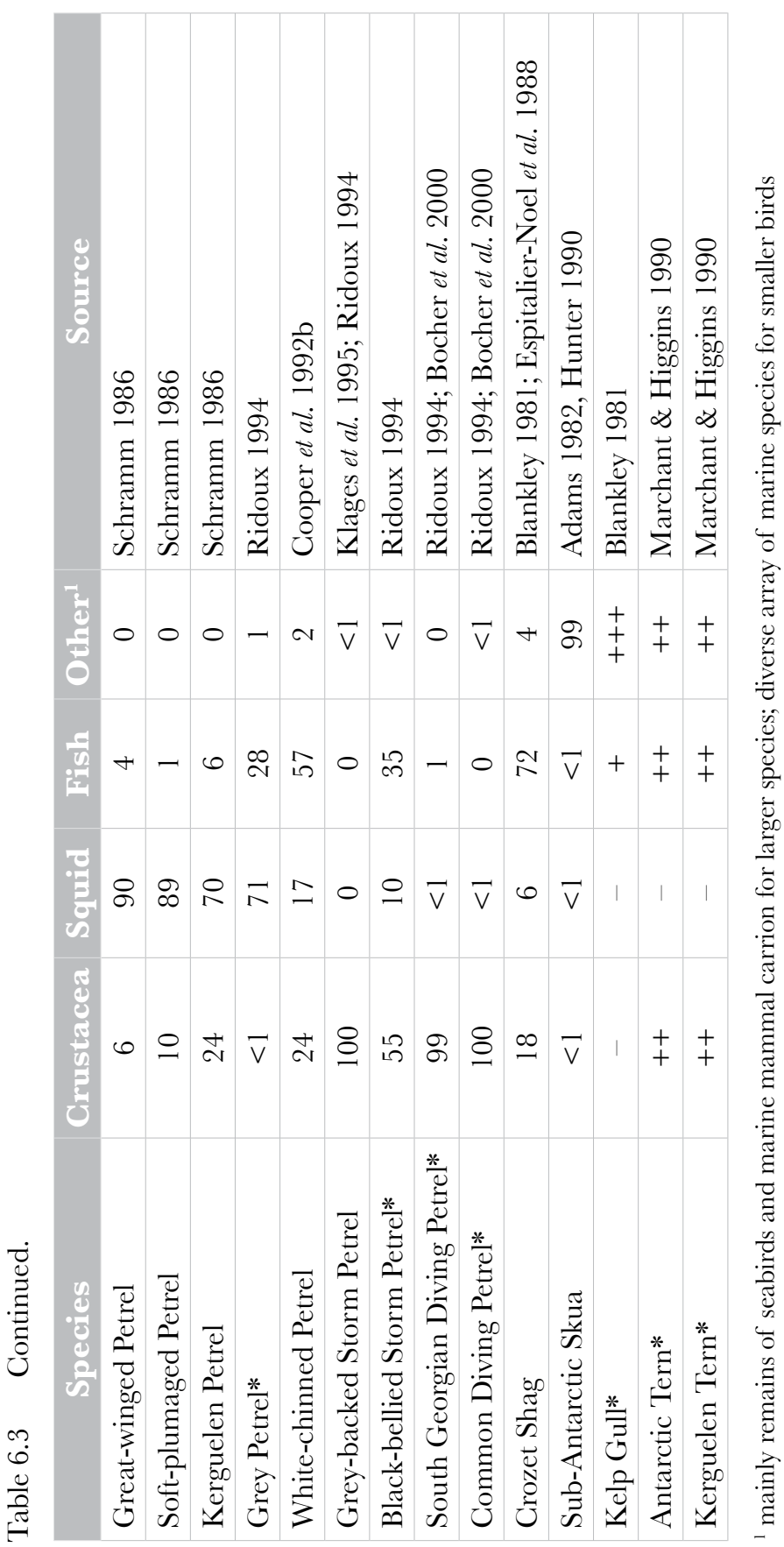


Fur seals typically make shallower dives than Elephant Seals, although this has not been studied at the Prince Edward Islands. At Macquarie Island, females of both species dive mainly at night, making short dives $(40-50 \mathrm{sec})$ to $10-20 \mathrm{~m}$ (maximum 100 m) (Goldsworthy 1999; Robinson et al. 2002). Fur seal scats collected at Marion Island suggest that both species feed predominantly on myctophid fish, primarily Electrona carlsbergi, Electrona subaspera, Gymnoscopelis fraseri, Gymnoscopelis piabilis, Krefftichthys andersoni, Metelectrona antarctica and Protomyctophum choriodon (Klages \& Bester 1998; Makhado 2002). Other fish and squid comprise a minor portion of the diet, with Antarctic Fur Seals occasionally taking some crustaceans (Table 6.3). The diets of both species vary seasonally, taking mainly $E$. carlsbergi, E. subaspera, $G$. fraseri and $M$. antarctica in winter, and $G$. piabilis, $P$. choriodon and Protomyctophum tennisoni in summer (Klages \& Bester 1998; Makhado 2002).

\subsubsection{Penguins}

Penguins are flightless pursuit divers (Harper et al. 1985). Diets of all four species breeding at the Prince Edward Islands have been well studied (Table 6.3; Ridoux 1994). There is little overlap between the diets of the three penguin genera (Adams \& Brown 1989). King Penguins provisioning chicks feed mainly on myctophid fish $(E$. carlsbergi, $K$. anderssoni and Protomyctophum spp.) and small squid (juvenile $K$. longimana), with little seasonal variation in diet (Adams \& Klages 1987). At the Crozet Islands, they regularly dive to $300 \mathrm{~m}$ (Pütz et al. 1998; Charrassin et al. 1999), diving deeper and more often when feeding chicks than when incubating (Charrassin et al. 1999). Gentoo Penguins take mainly fish (chiefly juvenile Notothenia squamifrons, with lesser amounts of myctophids and Channichthys rhinoceratus) and crustaceans (Euphausia vallentini all year, and Nauticaris marionis mainly in winter) (Adams \& Klages 1989). They usually dive to less than $40 \mathrm{~m}$ at Marion Island (Adams \& Brown 1983), but regularly dive to $>100 \mathrm{~m}$, occasionally $>200 \mathrm{~m}$ at the Crozet Islands (Bost $e t$ al. 1994). Both Macaroni and Rockhopper Penguins feed their chicks mainly on small crustaceans, E. vallentini and Thyssanoessa vicina, with small amounts of fish and squid, especially in Macaroni Penguins (Brown \& Klages 1987; Crawford et al. 2003c). Macaroni Penguins mostly dive to $10-80 \mathrm{~m}$, rarely to 160 m (Green et al. 1998), whereas Rockhopper Penguins mostly dive less than $40 \mathrm{~m}$, rarely to $70 \mathrm{~m}$ (Wilson et al. 1997; Tremblay \& Cherel 2000). Interannual variation in diet has been best studied in Macaroni Penguins, where there are considerable differences in the proportion of fish taken (Crawford et al. 2003c). Based on population estimates and diet samples collected in the 1980s, the penguin community at the Prince Edward Islands was estimated to consume 880000 tons of food annually (Adams et al. 1993).

\subsubsection{Albatrosses}

Albatrosses mainly forage by surface seizing (Harper et al. 1985). Diets of all species breeding at the Prince Edward Islands have been fairly well studied, 
except the Yellow-nosed Albatross (Table 6.3). Wandering Albatrosses are primarily scavengers, confined to the upper metre of the water column (Prince et al. 1994) and feeding on a wide diversity of squid (chiefly Histoteuthidae, Cranchiidae and Onychoteuthidae) and fish (Cooper et al. 1992a). Most prey is presumably moribund and dead animals scavenged by day (Cooper et al. 1993), caught at a rate of $2-4 \mathrm{~kg} \cdot \mathrm{d}^{-1}$ (Weimerskirch et al. 1994a). The diet of Wandering Albatrosses switched to include large amounts of offal and nontarget fish species caught in the Patagonian Toothfish Dissostichus eleginoides fishery in 1997, when the fishery started operating around the Prince Edward Islands (Nel et al. 2002a).

Grey-headed Albatrosses are more proficient divers, reaching depths of up to $6 \mathrm{~m}$ (Prince et al. 1994), but also take a wide range of mainly squid and fish prey, with slightly more crustaceans than Wandering Albatrosses (Hunter \& Klages 1989; Nel et al. 2000). Although large numbers were killed initially by the toothfish fishery, when some setting took place during the day and birds plunge-dived for bait (Nel et al. 2002b), they seldom scavenged from the fishery (Nel et al. 2000). Sooty albatrosses are the best divers among albatrosses, attaining depths of up to $12 \mathrm{~m}$ (Prince et al. 1994). They eat mainly squid, with the same species predominating as those eaten by the other albatrosses (Cooper \& Brown 1990; Cooper \& Klages 1995). Light-mantled Sooty Albatrosses take slightly more fish, and both species frequently scavenge dead seabirds and other carrion (Cooper \& Klages 1995).

\subsubsection{Petrels}

Most petrels breeding at the Prince Edward Islands feed by surface seizing or filtering (Harper et al. 1985), but some species are proficient divers, with White-chinned Petrels Procellaria aequinoctialis capable of diving up to $12 \mathrm{~m}$ (Huin 1994) and diving petrels Pelecanoides spp. to 50-60 m (Prince \& Jones 1992; Chastel 1994). Diet is varied, but the importance of crustaceans generally increases with decreasing body size (Table 6.3). The vast populations of Salvin's Prions and Blue Petrels feed mainly on euphausids (E. vallentini) and amphipods (chiefly Themisto gaudichaudii), with smaller amounts of fish (chiefly myctophids) (Steele \& Klages 1986; Gartshore et al. 1988a). Small crustaceans are equally important for storm petrels and diving petrels (Ridoux 1994). Dietary segregation among the two very similar species of diving petrels is achieved by almost complete spatial segregation at sea during the breeding season (Bocher et al. 2000). Among medium-sized petrels, squids dominate the diet of Pterodroma petrels (Schramm 1983), whereas fish and squid are important in the diets of White-chinned, Grey and Kerguelen Petrels Lugensa brevirostris (Schramm 1983; Cooper et al. 1992b; Ridoux 1994). Giant petrels are unusual among pelagic seabirds in having marked sexual dimorphism. The larger males mainly forage on the islands, scavenging from seal and penguin colonies, but also killing penguins and smaller petrels (Hunter \& Brooke 1992). Their larger size is an adaptation to compete successfully at carcasses (Hunter 
1983). The smaller females, by comparison, feed mainly at sea, taking more squid and fish (Hunter \& Brooke 1992).

\subsubsection{Other seabirds}

Crozet Shags are pursuit divers (Cooper 1985), feeding chiefly on benthic fish and the decapod crustacean $\mathcal{N}$. marionis (Blankley 1981; Espitalier-Noel et al. 1988). Sub-Antarctic Skuas are aggressive predators and scavengers, mainly associated with large penguin colonies on Marion Island (Hunter 1988), but they kill large numbers of adult burrowing petrels, especially on Prince Edward Island (Adams 1982; Ryan et al. 2003a). The gulls and terns are mainly inshore feeders, also obtaining some food from terrestrial sources (Blankley 1981; Ryan 1987b; Ridoux 1994).

\subsection{Distribution of pelagic predators at sea}

Where seals and seabirds forage depends on their travelling speed and breeding status. During the breeding season, when animals have eggs or dependent young ashore, they are constrained to forage within commuting distance of the islands. This distance varies as a function of travelling speed, and with stage of breeding. For example, seabirds typically travel much further during incubation, when they may leave the island for up to 10-20 days at a time, than when provisioning a small chick. As chicks grow, and feeding intervals increase, birds can once again travel further from the islands. By comparison, immature animals and adults who have completed their reproductive activities ashore are free to wander widely, in some cases migrating to distant non-breeding areas, or even circumnavigating the Southern Ocean (Croxall et al. 2005). In general, more is known about the movements of breeding animals, because they return to the islands regularly and thus can be tracked with various logging devices (which require recovery of devices) or transmitters (where deployment on breeders gives a good chance of device recovery) (Boyd 1997; Wilson et al. 2002). However, we know a little about the movements of non-breeding animals from tag recoveries (Gartshore et al. 1988b), one-time deployment of transmitters (BirdLife International 2004b) and from recently-developed longterm loggers (Croxall et al. 2005). Observations at sea also provide information on the general foraging range of different species, but for wide-ranging, highly mobile taxa like many seabirds it is not possible to differentiate birds from different colonies, or breeding adults from non-breeders, nor, for most species, can one distinguish adults from immatures.

\subsection{Pinnipeds}

Southern Elephant Seals range widely in the south-west Indian Ocean. During the two month post-breeding period, 13 adult females remained within $1500 \mathrm{~km}$ of Marion Island both to the north and the south of the island, spending most time in areas at the outer edge of their feeding range, largely within inter-frontal zones south of the Antarctic Polar Front (APF), and between 
the Subtropical Convergence (STG) and the sub-Antarctic Front (SAF). Four adult males, only one definitely born on Marion Island, behaved similarly during the post-breeding period (Malherbe 1998). Three post-moulting adult females ranged further afield, some $2000-3100 \mathrm{~km}$ distant to the APF and south to the Antarctic continental shelf, within the outer edge of the pack-ice (Jonker \& Bester 1998). Eleven post-moult adult males (not necessarily born at Marion Island) travelled widely between $40-55^{\circ} \mathrm{S}$ and $3-70^{\circ} \mathrm{E}$ (Bester et al. 2005). Twenty satellite-tracked immatures born on Marion Island spent most of their time upstream of the island during winter 2004 (Bester et al. 2005).

Movements of fur seals are little known. Lactating females of both species spend about 6 days at sea on average during foraging trips in mid-summer (Bester \& Bartlett 1990; Kirkman et al. 2002, 2003) and sub-Antarctic Fur Seals on average 25 days in winter (Kirkman et al. 2002). Of five lactating females tracked from the east coast of Marion Island, both species moved east along the 2 000-3 $000 \mathrm{~m}$ shelf break, with sub-Antarctic Fur Seals ranging to $1000 \mathrm{~km}$ from the island (Osbourne et al. 2002), similar to the maximum range recorded at Amsterdam Island (Georges et al. 2000). At Macquarie Island, where females of both species spend on average 3.4 days during foraging trips at sea in summer, foraging activity was concentrated at two sites, within $30 \mathrm{~km}$ and at $60 \mathrm{~km}$ north of the island (Robinson et al. 2002).

\subsubsection{Penguins}

Like seals, penguins are difficult to observe at sea, unless sea conditions are calm (Enticott 1986). Consequently, knowledge of foraging ranges of penguins around the Prince Edward Islands is mainly limited to maximum commuting distances, based on estimates of swimming speed and trip durations (Adams et al. 1993). When birds are provisioning chicks in summer, there is limited spatial overlap between species, with King Penguins feeding within 300-500 km of the islands (Adams 1987), Macaroni Penguins within 60-300 km (Brown 1987), Rockhopper Penguins within 5-150 km (Brown 1987), and Gentoo Penguins within $40 \mathrm{~km}$ (Adams \& Wilson 1987). Differences result mainly from differences in foraging trip durations and, to a lesser extent, the proportion of time at sea spent travelling, because all four species travel at 7-9 $\mathrm{km} \cdot \mathrm{h}^{-1}$ (Adams 1987; Adams \& Wilson 1987; Brown 1987). Birds provisioning large chicks spend more time travelling than do birds with small chicks (Adams 1987; Brown 1987). Diets of Rockhopper and Macaroni Penguins change significantly during the breeding season, probably reflecting changes in their foraging ranges (Brown et al. 1990).

Actual foraging areas of penguins from the Prince Edward Islands are poorly known, but it is likely that the major pelagic predators, King and Macaroni Penguins, do not disperse randomly around the islands. Tracking of King Penguins breeding at other sub-Antarctic islands show that birds forage mainly at frontal zones (Charrassin \& Bost 2001; Pütz 2002). At the Crozet Islands, immediately to the east of the Prince Edward Islands, King Penguins forage 
south of $45^{\circ} \mathrm{S}$ year round, travelling $500-750 \mathrm{~km}$ to the Antarctic Polar Front in summer and up to $1800 \mathrm{~km}$ during winter, south of the front into Antarctic waters, including into pack ice at $62^{\circ} \mathrm{S}$ (Charrassin \& Bost 2001). A similar situation probably occurs at the Prince Edward Islands, where observations of birds at sea are all from south of the islands, despite a bias in observer effort towards waters north of the islands (Enticott 1986).

Much less is known about the ranges of non-breeding penguins. Gentoo Penguins remain around the islands year round, often coming ashore at night even when not breeding (Williams 1995). They have not been sighted at sea far from the islands, although two birds seen near $45^{\circ} \mathrm{S}, 0^{\circ} \mathrm{E}$ as well as vagrant records at Gough Island $\left(40^{\circ} \mathrm{S}, 10^{\circ} \mathrm{W}\right)$ and South Africa indicate some potential for long-distance movements (Enticott 1986). Macaroni and Rockhopper Penguins probably remain fairly close to the breeding islands during the short pre-moult fattening period. One Macaroni Penguin satellite-tracked from Marion Island foraged up to $700 \mathrm{~km}$ south of the island (Osbourne et al. 2002). After moulting, they are absent from the islands for around five months in winter, when virtually nothing is known about their movements. No Macaroni Penguins have been observed at sea away from the islands, but two groups of Rockhopper Penguins were seen $750 \mathrm{~km}$ west-north-west of the islands in September, approximately one month before birds return to the islands to breed (Enticott 1986).

\subsubsection{Albatrosses}

Albatrosses are large enough to carry miniature data loggers and satellite transmitters, resulting in a large body of information on their movements (BirdLife International 2004b). Breeding adults range widely during incubation and on some trips provisioning large chicks, when they can remain away from their colonies for 10-20 days at a time, but are more constrained to the vicinity of the colony when feeding small chicks (Nel et al. 2000, 2002a). During the large-chick stage, many albatrosses and petrels alternate short and long foraging trips, primarily gathering food for the chick on the former, when adults lose body mass, and provisioning both themselves and their chicks on the latter (Weimerskirch et al. 1994b).

Wandering Albatrosses breeding at Marion Island range widely between $35-55^{\circ} \mathrm{S}$ and $0-52^{\circ} \mathrm{E}$, from Bouvet to the Crozet Islands and north to the African continental shelf (Nel et al. 2002a). Males typically forage further south than females (Nel et al. 2002a). During foraging trips, adults spend $60 \%$ of the time sitting, mostly at night (Weimerskirch et al. 2002). They use extremely efficient dynamic soaring to travel at an average speed of $54 \mathrm{~km} . \mathrm{h}^{-1}$ and regularly exceed $85 \mathrm{~km} . \mathrm{h}^{-1}$ (Weimerskirch et al. 2002). Heart rate in flight is similar to that of birds resting at sea and only 1.4 times resting heart rate on land (Weimerskirch et al. 2000). Landing and taking off (twice resting rate) are the most costly activities (Weimerskirch et al. 2000), with energy expenditure on foraging trips largely a function of the number of landings (Shaffer et al. 2003). 
Flight costs increase as flight direction heads into the wind, so birds structure foraging trips to exploit prevailing wind direction, making large anti-clockwise loops when heading north from colonies and clockwise loops when heading south (Weimerskirch et al. 2000). Movements are most constrained during the early chick-rearing period, when they typically remain within $400 \mathrm{~km}$ of the colony ( $\mathrm{Nel}$ et al. 2002a). After breeding, adults (and probably recently-fledged juveniles (Prince et al. 1998)) mainly travel east to the central Indian Ocean or waters off Australia (Nel et al. 2002a). During their sabbatical year between successful breeding attempts, most birds remain within the South Atlantic and South Indian Oceans between $20^{\circ} \mathrm{W}$ and $120^{\circ} \mathrm{E}$, but some circumnavigate the Southern Ocean (P.G. Ryan, unpublished data).

Grey-headed Albatrosses breeding at Marion Island range even more widely during incubation than Wandering Albatrosses, foraging between $40-55^{\circ} \mathrm{S}$ and $8-83^{\circ} \mathrm{E}$, moving up to $4000 \mathrm{~km}$ from the island and travelling up to $18000 \mathrm{~km}$ on one trip ( $\mathrm{Nel}$ et al. 2000). During this period, foraging is centred on eddies in the Subtropical Convergence across the entire range and more locally at the subAntarctic and Antarctic Polar Fronts (Nel et al. 2001). They are more constrained during chick rearing, when trips are shorter, mainly $<1500 \mathrm{~km}$ south-west of Marion Island $\left(47-57^{\circ} \mathrm{S}\right)$ ( Nel et al. 2000) and foraging is concentrated at both warm and cold eddies in the sub-Antarctic Front formed by the South-West Indian Ridge (Nel et al. 2001). During their sabbatical year between successful breeding attempts, most birds circumnavigate the Southern Ocean, heading eastwards with the prevailing westerly winds, but some remain within the South Atlantic and South Indian Oceans (P.G. Ryan, unpublished data). At least one of these resident birds was a male that attempted to breed during its sabbatical year (P.G. Ryan, unpublished data). Recently fledged juveniles probably also disperse eastwards; one juvenile from Marion Island was recovered in New Zealand within three months of fledging (Gartshore et al. 1988b).

Little is known about movements of Yellow-nosed Albatrosses breeding at Prince Edward Island, but observations at sea suggest they mainly forage in warmer waters north of the Subtropical Convergence. Adults feeding chicks at Amsterdam Island $\left(37.8^{\circ} \mathrm{S}, 77.5^{\circ} \mathrm{E}\right)$ undertake long flights to forage in tropical oceanic waters north (Weimerskirch 1998). Movements of sooty albatrosses breeding at the Prince Edward Islands also have been little studied, although observations at sea and differences in diet indicate that Dark-mantled birds forage mainly north of the islands, whereas Light-mantled birds forage further south (Cooper \& Klages 1995). One adult Light-mantled Sooty Albatross breeding at Marion Island ranged $45-60^{\circ} \mathrm{S}$, travelling more than $2500 \mathrm{~km}$ to southwest of Bouvet Island on two of four foraging trips (Osbourne et al. 2002). Elsewhere, Light-mantled Sooty Albatrosses from Macquarie Island forage mostly west of the island $48-66^{\circ} \mathrm{S}$ during incubation, travelling up to $2200 \mathrm{~km}$ from the island (Weimerskirch \& Robertson 1994), and Dark-mantled Sooty Albatrosses range further from their colony during incubation (average $600 \mathrm{~km}$ ) than when rearing chicks (Weimerskirch 1998). 


\subsubsection{Petrels}

Foraging movements of breeding giant petrels and White-chinned Petrels have been tracked from other colonies, but not from the Prince Edward Islands. Giant petrels satellite-tracked from South Georgia and Patagonia show marked sexual differences in foraging ranges, with females spending more time at sea and travelling further from their colonies than males (Quintana \& Dell'Arciprete 2002; BirdLife International 2004b). Northern Giant Petrels from South Georgia tend to forage further north than do Southerns, and males remain closer to colonies than do male Southerns (González-Solís et al. 2000). Outside the breeding season, giant petrels disperse widely in the Southern Ocean and adjacent continental waters. Ringed Southern and Northern Giant Petrel chicks from Marion Island have been recovered east of the islands, in Australia, New Zealand, Chile and at Macquarie Island, mainly within one year of fledging (Gartshore et al. 1988b). In addition, adult Northern Giant Petrels breeding at Marion Island have been sighted at Bouvet Island (Keith et al. 2002) and recovered along the coast of South Africa (Gartshore et al. 1988b), with birds ringed at seal colonies in central Namibia recaptured breeding on Marion Island (Gartshore et al. 1988b).

Breeding White-chinned Petrels travel even further than albatrosses because they fly both by night and day, travelling from the Crozet Islands to forage in southern African and Antarctic waters during incubation (Weimerskirch et al. 1999). During chick rearing they remain closer to their colonies, feeding along the shelf edge around the islands and in Antarctic waters south of the islands (Catard et al. 2000). Virtually all White-chinned Petrels leave the waters around the Prince Edward Islands in winter (May-August), probably moving north to forage around the African continental shelf (Rand 1963).

Most other petrels are too small to allow deployment of tracking or logging devices using current technologies, resulting in less detailed knowledge of their movements. Much of what we know comes from direct observations at sea, which gives only a crude idea of the total ranges of each species. Some species remain in the Southern Ocean year round, rarely venturing north of the Subtropical Convergence (e.g. Salvin's and Fairy Prions Pachyptila turtur, Blue, Kerguelen and Grey Petrels, Grey-backed Storm Petrels Garrodia nereis, and diving petrels), whereas others move north into temperate and tropical waters when not breeding (e.g. Great-wing Petrel and Black-bellied Storm Petrel Fregetta tropica). These differences are normally quite consistent, but in winter 1984 large numbers of Blue and Kerguelen Petrels irrupted north of the Subtropical Convergence throughout the Southern Ocean, suggesting that a large-scale perturbation occurred in the normal foraging areas of these species (Ryan et al. 1989). Range at sea also can be inferred from differences in diet. At Kerguelen, diving petrels are spatially segregated during the breeding season, with Common Diving Petrels Pelecanoides urinatrix feeding in inshore waters and South Georgian Diving Petrels Pelecanoides georgicus in pelagic waters (Bocher et al. 2000). This difference breaks down in winter, when both species feed on the same prey (Bocher et al. 2000). 


\subsubsection{Other seabirds}

Crozet Shags, Kelp Gulls and Kerguelen Terns remain at the Prince Edward Islands year round, foraging in coastal waters and, in the case of the gull and tern, in adjacent terrestrial habitats. By comparison, most sub-Antarctic Skuas and Antarctic Terns leave the islands in winter, moving north to temperate waters and, in the case of the skuas, some reach tropical waters, occasionally crossing the equator (Hockey et al. 2005).

\subsection{Movements between islands}

Individuals of two of the three seal species, marked at Marion Island, have been re-sighted elsewhere (Bester 1989), including the coast of South Africa (sub-Antarctic Fur Seal) and the Crozet Islands (Southern Elephant Seal). In addition, Elephant Seals marked at the Crozet Islands have hauled out to moult and breed at Marion Island (Mammal Research Institute, unpublished data). Elephant seals from Marion Island have been sighted on Prince Edward Island, where some may breed (Bester \& Hofmeyr 2005). However, in general, Elephant Seals show high levels of site fidelity, with some $50 \%$ of breeding females and $65 \%$ of breeding males hauling out within $5 \mathrm{~km}$ of their natal site at Marion Island (Hofmeyr 2000). Fur seals probably also exhibit some degree of site fidelity, with re-sightings of tagged females with pups at the same site over a number of years (Mammal Research Institute, unpublished data).

Most seabirds also show extremely high site fidelity, returning not only to their natal island to breed, but to the same colony on that island (Warham 1990). However, there is some movement between islands, both between Marion and Prince Edward Island (Ryan et al. 2003a) and more distant sub-Antarctic islands including the Crozet archipelago, $960 \mathrm{~km}$ farther east (Gartshore et al. 1988b; Cooper \& Weimerskirch 2003) and Bouvet Island, 2000 km westsouth-west (Keith et al. 2002). Most of these movements are made by young birds who subsequently return to their natal islands to breed, but at least some involve emigration (Cooper \& Weimerskirch 2003; Ryan et al. 2003a).

The main importance of such movements, other than maintaining genetic continuity between island populations in the case of effective dispersal, is the potential for seabirds to transport seeds and other propagules. Several widespread plants in the sub-Antarctic are adapted for long-distance dispersal by birds; e.g. Acaena spp. and Uncinia spp. have hooked seeds adapted for attaching to bird feathers. Alien plants also probably are dispersed by birds, including movement from Marion to Prince Edward Island (Ryan et al. 2003b). Seeds also may be transported in the gizzards of some seabirds. Petrels often contain hard-shelled seeds in their gizzards, and can store them there for months (Ryan \& Jackson 1987). They probably inadvertently eat the seeds at sea, mistaking them for food, in the same way they ingest large numbers of plastic particles (Ryan 1987a). The seeds may be released at the breeding islands if the carrier is killed (e.g. by a skua), and the seeds regurgitated together 
with the petrel's bones and feathers. Such a mechanism probably accounts for the peculiar distribution of the Island Tree Phylica arborea at islands in the south Atlantic and Indian Oceans.

\subsection{Recent population changes}

Populations of pelagic predators breeding on Marion Island have been monitored since the 1970s, with regular counts since the 1980s. Trends in seal populations are best monitored through pup counts, but this has been complemented by a comprehensive long-term mark-recapture programme for Southern Elephant Seals at Marion Island (Pistorius et al. 1999a, 2002, 2004; McMahon et al. 2003). Pup production of Elephant Seals is determined by annual marking at weaning of almost all pups born on Marion Island, and weekly checks of harems to assess pre-weaning mortality. Determining fur seal pup production is more difficult due to their greater range and numbers, coupled with the rough topography of many breeding sites and the inclination of pups to hide. Complete counts have only been conducted in a few years (Rand 1956; Condy 1978b; Kerley 1983a; Wilkinson \& Bester 1990; Hofmeyr et al. 1997, 2006). Counts of pups are conducted in February, when all pups have been born, but are still limited to land. Populations at Prince Edward Island are less well known, although recent expeditions have allowed further assessments of fur seal (Bester et al. 2003) and Elephant Seal numbers (Bester \& Hofmeyr 2005).

For seabirds, population monitoring involves annual counts of selected colonies (or subsets thereof) for surface-nesting species, with complete island counts at least every five years (e.g. Nel et al. 2002c; Crawford et al. 2003a, 2003b, 2003c, 2003d). Demographic parameters are estimated from individually-marked birds in several study colonies that have been followed since the early 1980s (Nel et al. 2002c). Burrow-nesting species are much harder to census accurately, so for these species there is very little information on trends. Unlike seals, all seabirds are monogamous, requiring bi-parental care to breed successfully (Warham 1990; Williams 1995). They also have fixed nest sites, at least during the egg stage, making censuses easier to conduct. The main problem with using counts of birds at breeding colonies as an index of population trends is that not all adults may elect to breed each year. However, without closelymonitoring colonies of individually-marked birds it is very difficult to estimate what proportion of pairs attempts to breed. In general, given the high adult survival rates of most seabirds, marked short-term fluctuations in breeding numbers are mainly due to changes in the proportion of adults breeding in successive years, whereas consistent long-term changes may reflect changes in the underlying population size.

\subsection{Pinnipeds}

The Prince Edward Island population of Southern Elephant Seals forms part of the Kerguelen stock, including Kerguelen, the Crozets and Heard Island 
(Hoelzel et al. 1993; Slade 1997), which has decreased across its range since the 1950s (Hindell \& Burton 1987; Guinet et al. 1992; Bester \& Wilkinson 1994). At Marion Island, pup numbers decreased 37.5\% from 1986 to 1997, at an average rate of 4.3\% per year from 1986-91 (Pistorius et al. 1999a). Pup numbers appeared to stabilise after 1994 (Pistorius et al. 2004). Compensatory responses to the decreasing population size included an earlier onset of reproduction, increased fecundity and faster pup growth (Pistorius et al. 2001; McMahon et al. 2003). However, mean pup weaning masses were significantly higher $(120.6 \mathrm{~kg})$ in the recent period of stable population size (McMahon et al. 2003) than when the population was decreasing (114.1 kg) (Burton et al. 1997). Density dependence in fecundity could not be demonstrated, suggesting an extrinsic form of control (Bradshaw et al. 2002). Similar stabilization in populations has occurred at Kerguelen (Guinet et al. 1999). There appears to have been a major alteration of food availability in the southern Indian Ocean, probably linked to environmental change, in the mid 1990s (McMahon et al. 2003, 2005). Food availability may drive Elephant Seal demography through its impact on adult survival (particularly of females; Pistorius et al. 1999a, 1999b, 2004; Pistorius \& Bester 2002) and/or juvenile survival and recruitment into the breeding population (Hindell 1991; McMahon et al. 2003).

Commercial sealing in the 18th and early 19th centuries severely impacted fur seal populations in the Southern Ocean, resulting in local extinctions at some sites. The Prince Edward Islands supported one of only three remnant populations of sub-Antarctic Fur Seals (Bester 1987; Kerley 1987), and probably were the main source area for re-colonization of the Crozets and Macquarie Island (Wynen et al. 2000). The historical status of Antarctic Fur Seals at the Prince Edward Islands is unclear, due to confusion between the two species (King 1959). However, genetic evidence indicates the Prince Edward Island population is part of a western stock, centred on South Georgia and Bouvet, rather than the eastern stock at Kerguelen and Macquarie Island (Wynen et al. 2000). Fur seal populations increased rapidly after the cessation of sealing, with c. 10\% per year growth at Marion Island between 1951 and the late 1980s (Wilkinson \& Bester 1990). Subsequently, growth has slowed to 5.2\% per year for sub-Antarctic Fur Seals (1994/95 to 2003/04; Hofmeyr et al. 2006), whereas Antarctic Fur Seal numbers have grown at grown at 14.8\% per year over the past 21 years (Hofmeyr et al. 2006). The demographic changes underpinning the slower population growth rate in sub-Antarctic Fur Seals are unknown. Some insights on prey availability can be gained from the rate of pup provisioning and growth rate, with body mass at weaning important for future survival (Georges \& Guinet 2000). Generally, poor foraging conditions result in longer foraging trips by fur seal mothers, and slower pup growth (Boyd et al. 1997; McCafferty et al. 1998; Kirkman et al. 2003; Lea et al. 2006). Foraging trip durations by lactating females of both species were shorter in 1987 (Bester \& Bartlett 1990) than in 1998-2000, but 1987 may simply have been a favourable year (Kirkman et al. 2002, 2003). No changes in pup growth rates were found at Marion Island during 1993-2000, nor was there any 
evidence that growth was affected by El Niño Southern Oscillation (ENSO) events (Kirkman et al. 2002).

\subsubsection{Penguins}

The King Penguin is the only penguin species that has apparently not decreased in numbers at the Prince Edward Islands over the last two decades (Crawford et al. 2003a). The number of colonies has increased over the last 50 years, probably linked to recovery from past exploitation, but there has been little consistent trend in the breeding population over the last 20 years (Crawford et al. 2003a). Its ability to maintain a high population while other penguins have been decreasing may relate to its distinctive diet and/or to its greater foraging range, which presumably enables it to adapt more readily to local changes in prey distribution. However, numbers of chicks surviving to the end of winter each year were correlated at the two largest colonies on Marion Island (Kildalkey and King Penguin Bay) during 1987-2002 (Grawford et al. 2003a), suggesting consistent inter-annual variation in breeding conditions, presumably linked to differences in prey availability. Winter survival of King Penguin chicks was exceptionally high in 1997, a year with a large ENSO event (Crawford et al. 2003f).

Gentoo Penguins are listed as Near-threatened globally (BirdLife International 2004a), and their numbers have decreased by $c .40 \%$ at Marion Island over the last 10 years (Crawford et al. 2003d). Most of the decrease took place between 1995 and 2000, with little decrease since 2001 (Crawford et al. 2003d). It is uncertain whether there has been a corresponding decrease at Prince Edward Island, because there hasn't been a spring census there since 1984 (Adams \& Wilson 1987), but a mid-summer count suggests they may have decreased, with the colony at Boggel disappearing (Ryan et al. 2003a). Human disturbance may have contributed to the decrease close to the base on Marion Island, where at least two colonies have disappeared since the base was built in 1948 (Crawford 1952; Crawford et al. 2003d), but changes in food availability are thought to be responsible for the island-wide decrease (Crawford et al. 2003a, 2003d). Breeding success was exceptionally low in 1997, a year with a large ENSO event, when birds also started breeding later than usual (Crawford et al. 2003f).

Macaroni and Rockhopper Penguins are both listed as globally Vulnerable due to consistent population decreases at several colonies throughout the Southern Ocean (BirdLife International 2004a). The population of Macaroni Penguins has decreased by 10-15\% over 15 years at Marion Island (Crawford et al. 2003c) and by closer to 50\% at Prince Edward Island (Ryan et al. 2003a). At Marion Island, there have been steady decreases at several well-studied small colonies, and although the total occupied area at the two large colonies has remained constant, the density of nests has decreased consistently at both Bullard and Kildalkey (Crawford et al. 2003c). Breeding success has increased over the last decade, but appears to have been too low to maintain a stable population (Crawford et al. 2003c). The decrease in the population of Rockhopper Penguins has been even more marked at Marion Island, falling by 
c. $40 \%$ in 14 years (Crawford et al. 2003b). Most of the decrease occurred in the late 1990s, with the breeding population decreasing by an average of $12 \%$ per year from 1994/95 to 2001/02 (Crawford et al. 2003b). The population at Prince Edward Island has apparently remained stable over the last two decades (Ryan et al. 2003a), although the accuracy of the previous estimate from Prince Edward Island is unknown. The increasing fur seal population may account for some of the decrease in Macaroni Penguins at Prince Edward Island (Ryan et al. 2003a), but changes in food availability are thought to be mainly responsible for the reductions in both Eudyptes penguins (Crawford et al. 2003b, 2003c; Hilton et al. 2006). This is supported, at least for Rockhopper Penguins, by the low fledging mass of chicks relative to other colonies (Crawford et al. 2003b).

\subsubsection{Albatrosses}

All five albatrosses are listed as Threatened or Near-threatened, primarily due to accidental mortality in long-line fisheries (BirdLife International 2004a). Birds are caught while trying to snatch baits during longline setting, dragged under and drowned (Brothers 1991). Numbers of Wandering Albatrosses at Marion Island decreased between the 1970s and early 1980s, presumably due to mortality on pelagic long-lines targeting tuna, but have since increased through the late 1980s and 1990s (Nel et al. 2002c, 2003), stabilising since 2000 (Crawford et al. 2003a). Adult survival is correlated with Japanese long-line fishing effort in the southern Indian Ocean, with females having a lower survival rate because they forage further north than males, overlapping more with tuna fishing effort (Nel et al. 2003). The excess of males in the breeding population reduces population fecundity (Mills \& Ryan 2005), and may lead to social disruption (Ryan 2002). Wandering Albatrosses have benefited from the long-line fishery for Patagonian Toothfish that commenced at the Prince Edward Islands in 1997, because very few birds have been killed (Nel \& Nel 1999; Nel et al. 2002b), and supplemental food obtained by scavenging from this fishery has increased adult survival and halted the long-term decrease in breeding success (Nel et al. 2003). Wandering Albatross demography also is influenced by broad-scale environmental factors, with the proportion of first-time breeders correlated with ENSO indices (Nel et al. 2003) and peak numbers of pairs breeding during the 1997/98 ENSO year (Crawford et al. 2003f). Past population trends at Marion Island can be predicted using a simple model incorporating observed estimates for survival, breeding success and the proportion of different age classes breeding (including the proportion of firsttime breeders) (Nel et al. 2003). Population trends and annual estimates of adult survival are correlated with those of the population studied on Possession Island in the Crozets, and the closely-related Amsterdam Albatross Diomedea amsterdamensis, but not South Georgia, suggesting Wandering Albatross demography is driven by factors operating at an ocean basin scale (Nel et al. 2002c, 2003).

Grey-headed Albatross numbers at Marion Island have remained roughly constant over the last decade ( $\mathrm{Nel}$ et al. 2002c; Crawford et al. 2003a), despite an 
estimated 1 000-2 500 birds killed during the first four years of the Patagonian Toothfish fishery in the Prince Edward Islands' Exclusive Economic Zone (EEZ) in late 1990s (Nel et al. 2002b). Virtually all birds killed were breeding adults, with a strong male bias (Ryan \& Boix-Hinzen 1999; Nel et al. 2002b), probably leading to an excess of females in the population. Their foraging range overlaps with tuna fisheries in the southern Indian Ocean ( Nel et al. 2000), with mainly immature birds killed on tuna long-lines off Australia (Gales 1998) and South Africa (P.G. Ryan, unpublished data). Less is known about the population dynamics of Yellow-nosed Albatrosses, because they only breed on Prince Edward Island. A recent mid-summer survey suggests that their numbers also have remained fairly constant over the last two decades (Ryan et al. 2003a). This contrasts with their status on Amsterdam Island, where the population has fallen by $50 \%$ from $1980-2000$ and is decreasing by $3.6 \%$ per year (Weimerskirch \& Jouventin 1998; Weimerskirch 2004). However, the decrease at this colony is now thought to be largely due to avian cholera Pasturella multicida and another bacterial disease (Erysipelothrix rhusiopathidae), probably introduced with poultry kept at the island's base (Weimerskirch 2004). Yellow-nosed Albatrosses are killed in long-line fisheries for tuna (Gales 1998; Ryan et al. 2002) and toothfish, with an estimated 500-1 200 killed in the first four years of toothfish fishing at the Prince Edward Islands (Nel et al. 2002b). Like Grey-headed Albatrosses, most birds killed were adult males (Nel et al. 2002b). Mortality of both species in the sanctioned fishery virtually ceased once a ban on day-time setting was enforced ( $\mathrm{Nel}$ et al. 2002b).

Numbers of sooty albatrosses are less easy to monitor, because they breed at low densities on inaccessible cliffs, and are less visible than other albatrosses. However, count data suggest that populations of both species have decreased consistently over the last 10-20 years at Marion Island (Crawford et al. 2003a). Decreases have been most marked among Dark-mantled Sooty Albatrosses, which appear to have almost halved in numbers between the late 1990s and early 2000s (Crawford et al. 2003a). There was no evidence for a decrease in numbers at Prince Edward Island during the summer survey in 2001, but the accuracy of estimates made in the 1970s and 1980s are unknown (Ryan et al. 2003a). Similar decreases have been reported for Light-mantled Sooty albatrosses at the Crozets over the last 20 years (Weimerskirch \& Jouventin 1998). The main threat appears to be long-line mortality (Gales 1998, BirdLife International 2004a), although diseases may be a problem for Dark-mantled Sooty Albatrosses at Amsterdam Island (Weimerskirch 2004).

\subsubsection{Petrels}

Both giant petrels are listed as Threatened or Near-threatened, primarily due to accidental mortality in long-line fisheries, although disturbance at breeding colonies is a significant problem for Southern Giant Petrels (BirdLife International 2004a). Counts of breeding Northern Giant Petrels at the Prince Edward Islands have increased, probably linked to increases in numbers of 
fur seals (Nel et al. 2002c). By comparison, the population of Southern Giant Petrels breeding at Marion Island almost halved from the 1980s and early 1990s to late 1990s and 2000s (Nel et al. 2002c; Crawford et al. 2003a), but the population at Prince Edward Island is stable or increasing (Ryan et al. 2003a). The difference between the two island populations may be a function of high levels of disturbance on Marion Island, especially during the cat eradication programme, although the sharp decrease at Marion occurred several years after cat operations ceased (Nel et al. 2002c). Emigration of chicks ringed on Marion Island in the late 1980s to breed on Prince Edward Island is consistent with this hypothesis (Ryan et al. 2003a), but because no chicks have been banded on Prince Edward Island we have no way of telling if similar movement is occurring in the opposite direction. An estimated 200-400 birds were killed during the first four years of toothfish fishing at the Prince Edward Islands (Nel et al. 2002b), and they are also killed on other long-line fisheries (Ryan et al. 2002). Small numbers are also killed by ingesting fisheries wastes or becoming entangled in discarded fishing gear (Nel \& Nel 1999).

Numbers of burrowing petrels are much harder to monitor accurately, and there are few data on population trends at the Prince Edward Islands. Whitechinned Petrels are listed as Vulnerable (BirdLife International 2004a), with populations at Bird Island, South Georgia, having decreased by $c .28 \%$ over 17 years (Berrow et al. 2000). Occupied burrows in a study colony at Marion Island also decreased in the late 1990s (Nel et al. 2002c). Decreases at South Georgia have resulted partly from habitat loss due to increases in numbers of Antarctic Fur Seals, but probably are mainly due to long-line mortality (Berrow et al. 2000). It is the species most frequently killed on long-lines in most Southern Ocean fisheries, with an estimated $6000-14000$ birds killed in the first four years of toothfish fishing at the Prince Edward Islands (Nel et al. 2002b), and large numbers killed in other regional fisheries (Barnes et al. 1997; Ryan et al. 2002). The impact of mortality in the toothfish fishery is exacerbated by most birds killed being adult males (Ryan \& Boix-Hinzen 1999). It also was impacted by introduced cats at Marion Island, with breeding success greater in cat-free areas (Van Rensburg \& Bester 1988). Breeding success in 1996-2000, after the removal of cats, was almost twice that prior to their removal (P.G. Ryan, unpublished data).

Grey Petrels are listed as Near-threatened due to long-line mortality and significant predation by introduced predators at breeding islands (BirdLife International 2004a). Relatively few were killed on toothfish longlines around the Prince Edward Islands (Nel et al. 2002b), but as a winter breeder it was one of the species hardest hit by cat predation on Marion Island (Van Rensburg \& Bester 1988; Newton \& Fugler 1989). Great-winged Petrels also breed in winter, and their breeding success increased from $0-20 \%$ to $60-64 \%$ following the removal of cats (Cooper et al. 1995). Breeding success of other, summer breeding petrels also increased in cat-free areas or after the removal of cats (Van Rensburg \& Bester 1988; Cooper et al. 1995). However, there are no accurate data to monitor the recovery of burrowing petrel populations at 
Marion Island following the eradication of cats. It would be very interesting to know whether immigration is occurring, although it seems likely given the rapid recolonisation of other former petrel colonies following the removal of predators (e.g. Harper 1983).

\subsubsection{Other seabirds}

Although not listed as globally threatened (BirdLife International 2004a), perhaps the most endangered seabird at the Prince Edward Islands is the Crozet Shag, a localised endemic confined to the Prince Edward and Crozet Islands. Numbers of breeding pairs have decreased at Marion Island by at least $50 \%$ since the 1980 s, and by $12 \%$ annually between $1994 / 95$ and $2002 / 03$, excluding the anomalous $1997 / 98$ season, when some $25 \%$ of adults didn't attempt to breed (Crawford et al. 2003e). There has been a corresponding decrease at Prince Edward Island (Ryan et al. 2003a). Reasons for this decrease are unclear, but probably relate to a reduction in food availability (Crawford et al. 2003e). Their decrease mirrors that in the other inshore-feeding pursuit diver, the Gentoo Penguin (Crawford et al. 2003d).

Numbers of sub-Antarctic Skuas appear to have decreased at Marion Island over the last 15 years, possibly linked to a reduction in penguin populations (Crawford et al. 2003a), although small numbers were killed by toothfish longlines (Nel et al. 2002b) and by traps set for cats (Bester et al. 2002). At Prince Edward Island, skuas rely much more heavily on burrowing petrels as a source of food, and the count in 2001 was much higher than any previous estimate, but this was probably due to better coverage in 2001 (Ryan et al. 2003a). Kelp Gulls may also have decreased at Marion Island (Crawford et al. 2003a), but reliability of counts is low. Kerguelen Terns are confined to the Kerguelen Arc islands and are listed as Near-threatened globally (BirdLife International 2004a). Their numbers apparently have decreased at Prince Edward Island over the last 20 years, corresponding with an increase at Marion Island following the removal of cats (Ryan et al. 2003a).

\subsection{Summary of human impacts on pelagic predators}

Although the Prince Edward Islands remain largely untransformed, wilderness areas, human actions have had some significant impacts, both directly and indirectly, on the region's pelagic predators. Historically, there was commercial exploitation of seals and seabirds (mainly King Penguins) for their skins (fur seals) and oil, mainly during the 19th and early 20th centuries (Cooper \& Headland 1991). This led to dramatic decreases in all seal populations (Richards 1992). Some whaling also took place in the island's waters (Cooper \& Avery 1986). Shore-based gangs of sealers doubtless also exploited a wide range of the larger seabirds for food, and introduced a variety of organisms alien to the islands, including House Mice Mus musculus to Marion Island (Watkins \& Cooper 1986). Commercial exploitation on land ceased in the 1930s, although small numbers of live animals were removed up to the 1970 s for 
supplying zoos. There was little commercial fishing activity close to the islands until 1997, when a largely illegal fishery for Patagonian Toothfish developed, resulting in the formation of a sanctioned fishery within the islands' EEZ (Nel et al. 2002b). This fishery initially killed large numbers of albatrosses and large petrels, but implementation of mitigation measures, coupled with complete observer coverage of the sanctioned fishery, reduced this to acceptable levels (Nel et al. 2002b). More damaging have been long-line fisheries operating in more distant waters, notably the extensive fishery for tunas Thunnus spp. throughout the Southern Ocean, which has caused significant decreases in many albatross and petrel populations (Brothers 1991; Nel et al. 2002c, 2003; Ryan et al. 2002).

Recent human impacts ashore have largely been through disturbance and introduced predators. The establishment of a weather station on Marion Island in 1948, staffed year-round by contract personnel, resulted in localised disturbance to breeding seabirds and seals. Species vary in their tolerance of human disturbance, with species such as Gentoo Penguins (Crawford et al. 2003d) and Southern Giant Petrels (Nel et al. 2002c) being especially prone to disturbance during the breeding season. However, even relatively 'tolerant' species such as Wandering Albatrosses are affected by human disturbance (de Villiers et al. 2005). The most severe impacts have resulted from introductions of alien species to the islands. In terms of pelagic predators, the introduction of domestic cats to control mice around the base in 1949 (Watkins \& Cooper 1986), has had the most destructive impact, reducing populations and even causing local extinctions of several seabirds (Van Aarde 1980; Cooper \& Brown 1990). Cats have now been removed from the islands (Bester et al. 2002), but there is concern about the possible impacts of mice, which are proving to be significant predators of seabird chicks at other islands (Cuthbert \& Hilton 2004).

\subsection{Predicting the effects of climate change}

Little is known about the likely effects climate change will have on the populations of pelagic predators. There is some evidence that climate change has altered the breeding phenology of two penguin species at the Prince Edward Islands. The first Macaroni Penguin chicks apparently hatched c. 2 weeks earlier in the late 1990s (Crawford et al. 2003c) than in 1951 (Rand 1954). Occupation of colonies and laying dates of Gentoo Penguins were up to one month earlier in 2001 than during 1994-1998, but this is subject to considerable variation (Williams 1980; Crawford et al. 2003d), and there does not appear to be a longer-term trend compared with observations from 1948 (Crawford 1952) or 1951 (Rand 1954). There is no evidence of earlier breeding among Rockhopper Penguins (Rand 1954; Crawford et al. 2003b).

Probably the most significant impact will be if there are changes in oceanographic circulation around the islands, resulting in changes in food availability for different predator populations. Strong ENSO events appear to benefit some species and disadvantage others (Crawford et al. 2003f; Lea et 
al. 2006), and may be responsible for occasional irruptions outside of normal ranges, with concomitant high mortality (Ryan et al. 1989). Among Wandering Albatrosses, the proportion of first-time breeders is correlated with ENSO events, suggesting they provide good foraging conditions for birds considering breeding for the first time (Nel et al. 2003). Similarly, among Grey-headed Albatrosses, there is a strong correlation between breeding success and the Southern Oscillation Index (Fig. 6.1).

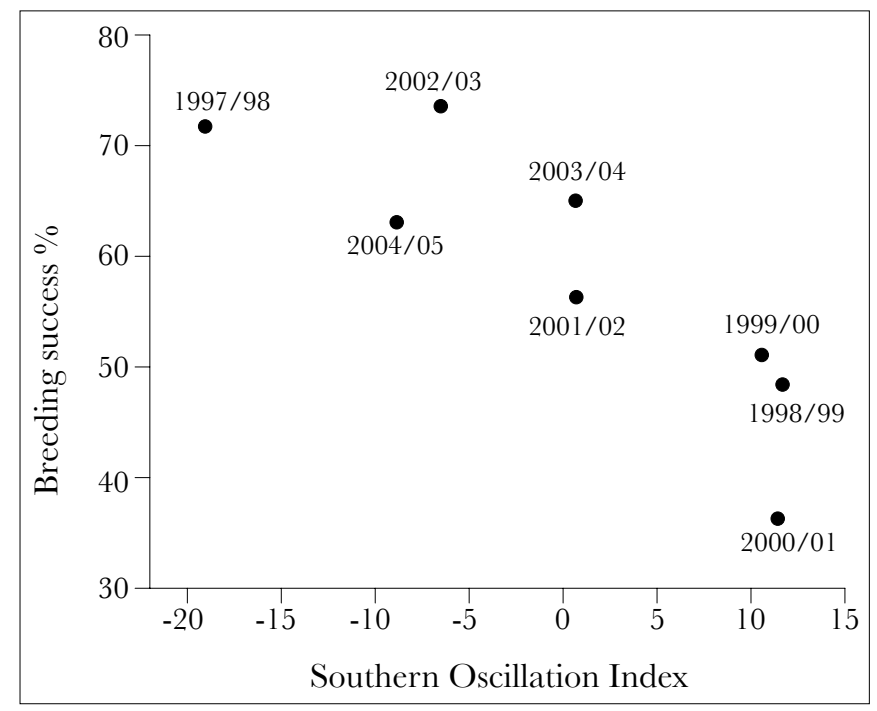

Figure 6.1 The relationship between breeding success of Grey-headed Albatrosses at Marion Island and the Southern Oscillation Index in the summer breeding season (average of monthly values from November-March).

Other population trends appear to be largely independent of short-term climatic fluctuations. There has been a consistent decrease in populations of inshore, pursuit-diving species (Gentoo and Rockhopper Penguins, Crozet Shag) over the last decade, apparently linked to changes in environmental conditions. Macaroni Penguins, as intermediate-distance feeders have been impacted to a lesser degree. By comparison, wide-ranging species such as King Penguins, albatrosses and some petrels may have benefited from environmental changes linked to increased variability in circulation patterns.

\subsection{Other pelagic predators}

Little is known about the abundance and distribution of pelagic predators that are not constrained to come ashore to breed in the waters around the Prince Edward Islands. Killer Whales Orcinus orca (Delphinidae) are seasonally common, predominantly in near-shore waters (Condy et al. 1978; Keith et al. 2001), with 25-30 hunting around Marion Island during their peak presence in early December 2000 (Pistorius et al. 2002). Elephant Seal pups 
remain in near shore waters during play and local post-weaning dispersion and are prone to predation (Guinet et al. 1992). They also target female Elephant Seals and penguins as they enter and exit the sea (Keith et al. 2001; Pistorius et al. 2002). Killer Whales, Long-finned Pilot Whales Globicephala melas (Delphinidae) and Sperm Whales Physeter macrocephalus (Physeteridae) often take toothfish off longlines during hauling (Ashford et al. 1996; B.P. Watkins, personal communication). Less is known about the presence of other cetaceans, but sightings and strandings confirm the presence of Strap-toothed Beaked Whales Mesoplodon layardii (Ziphiidae), Dusky Dolphin Lagenorhynchus obscurus, Hourglass Dolphin Lagenorhynchus cruciger and Southern Right Whale Dolphin Lissodelphis peronii (Delphinidae), Southern Right Whales Balaena Australis (Balaenidae), and Humpback Megaptera novaeangliae and Blue Whales Balaenoptera musculus (Balaenopteridae) in the waters around the Prince Edward Islands (La Grange 1962; Condy \& Burger 1975; Watkins 2000; B.M. Dyer \& M. Meyer, personal communication). Leopard Seals Hydrurga leptonyx (Phocidae) are infrequent visitors, occasionally hauling out in late winter and early spring, but are probably seasonally resident in offshore waters (Bester et al. 2006), taking penguins and possibly seals (Bester \& Roux 1986; Borsa 1990; Walker et al. 1998).

Even less is known about predatory fish around the islands. The Patagonian Toothfish (Nototheniidae) is a predatory species, mainly taking other fish, although smaller fish take more crustaceans (Gon \& Heemstra 1990). They in turn are prey for Sperm Whales. The largest predatory fish found off the islands is the Greenland Shark Somniosus microcephalus (Squalidae), a deep-water species that attains lengths of up to $4.5 \mathrm{~m}$ (Gon \& Heemstra 1990). Small numbers have been caught on long-lines set for toothfish in waters $200-500 \mathrm{~m}$ deep. They are opportunistic feeders, taking a wide range of prey, including fish, crustaceans and carrion (Gon \& Heemstra 1990).

Several seabirds are regular non-breeding visitors to the waters of the Prince Edward Island, including Black-browed Albatrosses Thalassarche melanophrys (Diomedeidae), Pintado Petrels Daption capense, Southern Fulmars Fulmarus glacialoides, Antarctic Prions Pachyptila desolata, White-headed Petrels Pterodroma lessonii, Little Puffinus assimilis and Sooty Shearwaters Puffinus griseus (Procellariidae), and Wilson's Storm Petrels Oceanites oceanicus (Hydrobatidae) (Appendix XI). Some of these species occasionally come ashore, and may even breed in small numbers on Prince Edward Island. Several other seabirds and seal species are vagrants to the island's waters, including one record of Cape Fur Seal Arctocephalus pusillus pusillus (Otariidae) and one Weddell Seal Leptonychotes weddellii (Phocidae) ashore at Marion Island (Kerley 1983b; Skinner \& Smithers 1990).

\subsection{Acknowledgements}

We thank our many colleagues, students and field assistants who have collected data on seabirds and seals at the Prince Edward Islands over the last 25 years. 
Special thanks go to John Cooper and Rob Crawford, for leading much of the research on seabirds, and Greg Hofmeyr for his endeavours in the field and inputs to this chapter.

\subsection{References}

Adams, N.J. 1982. Subantarctic Skua prey remains as an aid for rapidly assessing the status of burrowing petrels at Prince Edward Island. Cormorant 10, 97-102.

Adams, N.J. 1987. Foraging range of King Penguins (Aptenodytes patagonicus) during summer at Marion Island. Fournal of Zoology, London 212, 475-482.

Adams, N.J. \& Brown, C.R. 1983. Diving depths of the Gentoo Penguin (Pygoscelis papua). Condor 85, 503-504.

Adams, N.J. \& Brown, C.R. 1989. Dietary differentiation and trophic relationships in the sub-Antarctic penguin community at Marion Island. Marine Ecology Progress Series 57, 249-258.

Adams, N.J. \& Klages, N.T.W. 1987. Seasonal variation in the diet of the King Penguin (Aptenodytes patagonicus) at sub-Antarctic Marion Island. Fournal of Zoology, London 212, 303-324.

Adams, N.J. \& Klages, N.T. 1989. Temporal variation in the diet of the Gentoo Penguin Pygoscelis papua at sub-Antarctic Marion Island. Colonial Waterbirds 12, 30-36.

Adams, N.J., Moloney, C.L. \& Navarro, R. 1993. Estimated food consumption by penguins at the Prince Edward Islands. Antarctic Science 5, 245-252.

Adams, N.J. \& Wilson, M.-P. 1987. Foraging parameters of Gentoo Penguins Pygoscelis papua at Marion Island. Polar Biology 7, 51-56.
Ashford, J.R., Rubilar, P.S. \& Martin, A.R. 1996. Interactions between cetaceans and longline fishery operations around South Georgia. Marine Mammal Science 12, 452-457.

Barnes, K.N., Ryan, P.G. \& Boix-Hinzen, C. 1997. The impact of the hake Merluccius spp. longline fishery off South Africa on procellariiform seabirds. Biological Conservation 82, 227-234.

Bearhop, S., Phillips, R.A., McGill, R., Cherel, Y., Dawson, D. \& Croxall, J.P. 2006. Stable isotopes indicate sex-specific foraging and long-term individual foraging specialisation in diving seabirds. Marine Ecology Progress Series 311, 157-164.

Berrow, S.D., Croxall, J.P. \& Grant, S.D. 2000. Status of White-chinned Petrels Procellaria aequinoctialis Linnaeus 1758, at Bird Island, South Georgia. Antarctic Science 12, 399-405.

Bester, M.N. 1982. Distribution, habitat selection and colony types of the Amsterdam Island Fur Seal Arctocephalus tropicalis at Gough Island. Journal of Zoology, London 196, 217-231.

Bester, M.N. 1987. The Subantarctic Fur Seal Arctocephalus tropicalis at Gough Island (Tristan da Cunha Group). In: Proceedings of the Fur Seal Workshop, Cambridge, April 1984. NOAA Technical Report NMFS 51, 57-60.

Bester, M.N. 1989. Movements of Southern Elephant Seals and Subantarctic Fur Seals in relation to Marion Island. Marine Mammal Science 5, 257-265. 
Bester, M.N. \& Bartlett, P.A. 1990. Attendance behaviour of Antarctic and Subantarctic Fur Seal females at Marion Island. Antarctic Science 2, 309-312.

Bester, M.N., Bloomer, J.P., Van Aarde, R.J., Erasmus, B.H., Van Rensburg, P.J.J., Skinner, J.D., et al. 2002. A review of the successful eradication of Feral Cats from sub-Antarctic Marion Island, southern Indian Ocean. South African fournal of Wildlife Research 32, 65-73.

Bester, M., Bornemann, H., Burton, H., Pistorius, P., Plötz, J., Ramdohr, S., et al. 2005. Southern Elephant Seals at sea: the Marion Island connection. Abstract. "32nd Conference of the Zoological Society of Southern Africa", 12-15 July 2005, Rhodes University, Grahamstown.

Bester, M.N. \& Hofmeyr, G.J.G. 2005. Numbers of Elephant Seals at Prince Edward Island, Southern Ocean. South African Fournal of Wildlife Research 35, 85-88.

Bester, M.N., Hofmeyr, G.J.G., Kirkman, S.P., Chauke, L.F., De Bruyn, P.J.N., Ferreira, S.M., et al. 2006. The Leopard Seal at Marion Island, vagrant or seasonal transient? South Afrian Fournal of Wildlife Research $\mathbf{3 6}$, 195-198.

Bester, M.N. \& Roussouw, G.J. 1994. Time budgets and activity patterns of Subantarctic Fur Seals at Gough Island. South African Fournal of Zoology 29, 168-174.

Bester, M.N. \& Roux, J-P. 1986. Summer presence of Leopard Seals Hydrurga leptonyx at the Courbet Peninsula, Iles Kerguelen. South African fournal of Antarctic Research 16, 29-32.
Bester, M.N., Ryan, P.G. \& Dyer, B.M. 2003. Population numbers of Fur Seals at Prince Edward Island, Southern Ocean. African Fournal of Marine Science 25, 549-554.

Bester, M.N. \& Van Jaarsveld, A.S. 1994. Sex-specific and latitudinal variance in postnatal growth of the Subantarctic Fur Seal (Arctocephalus tropicalis). Canadian fournal of Zoology 72, 1126-1133.

Bester, M.N. \& Wilkinson, I.S. 1994. Population ecology of Southern Elephant Seals Mirounga leonina at Marion Island. In: Le Boeuf, B.J. \& Laws, R.M. (Eds.). Elephant Seals; Population Ecology, Behavior, and Physiology. University of California Press, pp. 85-97.

BirdLife International. 2004a. Tracking Ocean Wanderers: The Global Distribution of Albatrosses and Petrels. Results from the Global Procellariiform Tracking Workshop, 1-5 September, 2003, Gordon's Bay, South Africa. BirdLife International, Cambridge.

BirdLife International. 2004b. Threatened Birds of the World (CD Rom). BirdLife International, Cambridge.

Blankley, W.O. 1981. Marine food of Kelp Gulls, Lesser Sheathbills and Imperial Cormorants at Marion Island (Subantarctic). Cormorant 9, 77-84.

Bocher, P., Cherel, Y. \& Hobson, K.A. 2000. Complete trophic segregation between South Georgian and Common Diving Petrels during breeding at Iles Kerguelen. Marine Ecology Progress Series 208, 249-264.

Boelhouwers, I., Meiklejohn, I., Holness, S. \& Hedding, D. 2008. Geology, geomorphology and climate change. In: Chown, S.L. \& Froneman, P.W. (Eds.). The Prince Edward Islands. LandSea Interactions in a Changing Ecosystem. African Sun Media, Stellenbosch, pp. 65-96. 
Borsa, P. 1990. Seasonal occurrence of the Leopard Seal (Hydrurga leptonyx) in the Kerguelen Islands. Canadian fournal of Zoology 68, 405-408.

Bost, C.-A., Laage, J. \& Pütz, K. 1994. Maximal diving depth and diving patterns of the Gentoo Penguin Pygoscelis papua at the Crozet islands. Marine Ornithology 22, 237-244.

Boyd, I.L. 1997. Electronic marine mammals. Trends in Ecology and Evolution 12, 327-328.

Boyd, I.L., McCafferty, D.J. \& Walker, T.R. 1997. Variation in foraging effort by lactating Antarctic Fur Seals: response to simulated increased foraging costs. Behavioural Ecology and Sociobiology 40, 135-144.

Bradshaw, C.J.A., McMahon, C.R., Hindell, M.A., Bester, M.N. \& Pistorius, P.A. 2002. Do Southern Elephant Seals show density dependence in fecundity? Polar Biology 25, 650-655.

Brothers, N. 1991. Albatross mortality and associated bait loss in the Japanese long-line fishery in the Southern Ocean. Biological Conservation 55, 255-268.

Brooke, M. 2004. Albatrosses and Petrels across the World. Oxford University Press, Oxford.

Brown, C.R. 1986. Feather growth, mass loss and duration of moult in Macaroni and Rockhopper Penguins. Ostrich 57, 180-184.

Brown, C.R. 1987. Travelling speed and foraging range of Macaroni and Rockhopper Penguins at Marion Island. Fournal of Field Ornithology 58, 118-125.
Brown, C.R. \& Klages, N.T. 1987. Seasonal and annual variation in diets of Macaroni and Rockhopper Penguins at sub-Antarctic Marion Island. Fournal of Zoology, London 212 , 7-28.

Brown, C.R., Klages, N.T. \& Adams, N.J. 1990. Short and medium-term variation in the diets of penguins at Marion Island. South African Fournal of Antarctic Research 20, 13-20.

Burger, A.E. 1981. Food and foraging behaviour of Lesser Sheathbills at Marion Island. Ardea 69, 167-180.

Burger, A.E. 1982. Foraging behaviour of Lesser Sheathbills Chionis minor exploiting invertebrates at a subAntarctic island. Oecologia 52, 236-245.

Burger, A.E., Lindeboom, H.J. \& Williams, A.J. 1978. The mineral and energy contributions of guano of selected species of birds to the Marion Island terrestrial ecosystem. South African Journal of Antarctic Research 8, 59-70.

Burton, H.R., Arnbom, T., Boyd, I.L., Bester, M., Vergani, D. \& Wilkinson, I. 1997. Significant differences in weaning mass of Southern Elephant Seals from five sub-Antarctic islands in relation to population declines. In: Battaglia, B., Valencia, J. \& Walton, D.W.H. (Eds.). Antarctic Communities: Species, Structure and Survival. Springer, Berlin, pp. 335-338.

Catard, A., Weimerskirch, H. \& Cherel, Y. 2000. Exploitation of distant Antarctic waters and close shelfbreak waters by White-chinned Petrels rearing chicks. Marine Ecology Progress Series 194, 249-261.

Charrassin, J.-B. \& Bost, C.-A. 2001. Utilisation of the oceanic habitat by King Penguins over the annual cycle. Marine Ecology Progress Series 221, 285-297. 
Charrassin, J.-B., Bost, C.-A., Pütz, K., Lage, J., Dahier, T. \& le Maho, Y. 1999. Changes in depth utilization in relation to the breeding stage: a case study with the King Penguin Aptenodytes patagonicus. Marine Ornithology 27, 43-47.

Chastel, O. 1994. Maximum diving depths of Common Diving Petrels Pelecanoides urinatrix at Kerguelen Island. Polar Biology 14, 211-213.

Cherel, Y., Hobson, K.A. \& Weimerskirch, H. 2000. Using stable-isotope analysis of feathers to distinguish moulting and breeding origins of seabirds. Oecologia 122, 155-162.

Cherel, Y., Hobson, K.A. \& Weimerskirch, H. 2005. Using stable isotopes to study resource acquisition and allocation in procellariiform seabirds. Oecologia 145, 533-540.

Cherel, Y. \& Klages, N.T.W. 1998. A review of the food of albatrosses. In: Robertson, G. \& Gales, R. (Eds.). Albatross Biology and Conservation. Surrey Beatty \& Sons, Chipping Norton, pp. 113-136.

Condy, P.R. 1978a. The distribution and abundance of Southern Elephant Seals Mirounga leonina (Linn.) on the Prince Edward Islands. South African Journal of Antarctic Research 8, 42-48.

Condy, P.R. 1978b. The distribution, abundance and annual cycle of Fur Seals Arctocephalus spp. on the Prince Edward Islands. South African fournal of Wildlife Research 8, 159-168.

Condy, P.R. 1979. Annual cycle of the Southern Elephant Seal Mirounga leonina (Linn.), at Marion Island. South African Fournal of Zoology 14, 95-102.

Condy, P.R. \& Burger, A. 1975. Southern Right Whale at Marion Island. South African Fournal of Science 71, 349.
Condy, P.R., Van Aarde, R.J. \& Bester, M.N. 1978. The seasonal occurrence and behaviour of killer whales Orcinus orca at Marion Island. Journal of Zoology, London 184, 449-464.

Cooper, J. 1985. Foraging behaviour of non-breeding Imperial Cormorants at the Prince Edward Islands. Ostrich 56, 96-100.

Cooper, J. \& Avery, G. (Eds.). 1986. Historical sites at the Prince Edward Islands. South African National Scientific Programmes Report 128, 1-77.

Cooper, J., Brooke, M.de L., Burger, A.E., Crawford, R.J.M., Hunter, S. \& Williams, A.J. 2001. Aspects of the breeding biology of the Northern Giant Petrel (Macronectes halli) and the Southern Giant Petrel (Macronectes giganteus) at sub-Antarctic Marion Island. International fournal of Ornithology 4, 53-68.

Cooper, J. \& Brown, C.R. 1990. Ornithological research at the subAntarctic Prince Edward Islands: a review of achievements. South African Fournal of Antarctic Research 20, 40-57.

Cooper, J., Fourie, A. \& Klages, N.T.W. 1992b. The diet of the Whitechinned Petrel Procellaria aequinoctialis at subAntarctic Marion Island. Marine Ornithology 20, 17-24.

Cooper, J. \& Headland, R.K. 1991. A history of South African involvement in Antarctica and at the Prince Edward Islands. South African Fournal of Antarctic Research 21, 77-91.

Cooper, J., Henley, S.R. \& Klages, N.T.W. 1992a. The diet of the Wandering Albatross Diomedea exulans at Subantarctic Marion Island. Polar Biology 12, 477-484. 
Cooper, J. \& Klages, N.T.W. 1995. The diets and dietary segregation of sooty albatrosses (Phoebetria spp.) at Subantarctic Marion Island. Antarctic Science 7, 15-23.

Cooper, J., Marais, A.v.N., Bloomer, J.P. \& Bester, M.N. 1995. A success story: breeding of burrowing petrels (Procellariidae) before and after the eradication of Feral Cats Felis catus at subantarctic Marion Island. Marine Ornithology 23, 33-37.

Cooper, J. \& Weimerskirch, H. 2003. Exchange of the Wandering Albatross Diomedea exulans between the Prince Edward and Crozet Islands: implications for conservation. African Fournal of Marine Science 25, 519-523.

Cooper, J., Wilson, R.P. \& Adams, N.J. 1993. Timing of foraging by the Wandering Albatross Diomedea exulans. Proceedings of the NIPR Symposium on Polar Biology 6, 55-61.

Crawford, A.B. 1952. The birds of Marion Island, South Indian Ocean. Ети 52, 73-85.

Crawford, R.J.M. \& Cooper, J. 2003. Conserving surface nesting seabirds at the Prince Edward Islands: the roles of research, monitoring and legislation. African Fournal of Marine Science 25, 415-426.

Crawford, R.J.M., Cooper, J., du Toit, M., Greyling, M.D., Hanise, B., Holness, C.L., et al. 2003d. Population and breeding of the Gentoo Penguin Pygoscelis papua at Marion Island, 1994/95-2002/03. African Fournal of Marine Science 25, 463-474.

Crawford, R.J.M., Cooper, J. \& Dyer, B.M. 2003c. Population of the Macaroni Penguin Eudyptes chrysolophus at Marion Island, 1994/95-2002/03, with information on breeding and diet. African fournal of Marine Science 25, 475-486.
Crawford, R.J.M., Cooper, J., Dyer, B.M., Greyling, M.D., Klages, N.T.W., Nel, D.C., et al. 2003b. Decrease in numbers of the Eastern Rockhopper Penguin Eudyptes chrysocome filholi at Marion Island, 1994/95-2002/03. African fournal of Marine Science 25, 487-498.

Crawford, R.J.M., Cooper, J., Dyer, B.M., Greyling, M.D., Klages, N.T.W., Ryan, P.G., et al. 2003a. Populations of surface nesting seabirds at Marion Island, 1994/95-2002/03. African Journal of Marine Science 25, 427-440.

Crawford, R.J.M., Cooper, J., Dyer, B.M., Wolfaardt, A.C., Tshingana, D., Spencer, K., et al. 2003e. Population, breeding, diet and conservation of the Crozet Shag Phalacrocorax [atriceps] melanogenis at Marion Island, 1994/952002/03. African Fournal of Marine Science 25, 537-547.

Crawford, R.J.M., Duncombe Rae, C.M., Nel, D.C. \& Cooper, J. 2003f. Unusual breeding by seabirds at Marion Island during 1997/98. African Fournal of Marine Science 25, 453-461.

Croxall, J.P., Silk, J.R.D., Phillips, R.A., Afanasyev, V. \& Briggs, D.R. 2005. Global circumnavigations: tracking year-round ranges of nonbreeding albatrosses. Science 307, 249-250.

Cuthbert, R.J. \& Hilton, G.M. 2004. Introduced House Mice Mus musculus: a significant predator of endangered and endemic birds on Gough Island, South Atlantic Ocean? Biological Conservation 117, 483-489.

Daneri, G.A. \& Carlini, A.R. 2002. Fish prey of Southern Elephant Seals, Mirounga leonina, at King George Island. Polar Biology 25, 739-743.

Daneri, G.A., Carlini, A.R. \& Rodhouse, P. 2000. Cephalopod diet of the Southern Elephant Seal, Mirounga leonina, at King George Island, South Shetland Islands. Antarctic Science 12, 16-19. 
de Villiers, M.S., Cooper, J. \& Ryan, P.G. 2005. Individual variability of behavioural responses by Wandering Albatrosses (Diomedea exulans) to human disturbance. Polar Biology 28, 255-260.

Duffy, D.C. \& Jackson, S. 1986. Diet studies of seabirds: a review of methods. Colonial Waterbirds 9, 1-17.

Enticott, J.W. 1986. Distribution of penguins at sea in the southeastern Atlantic and southwestern Indian Oceans. Cormorant 13, 118-142.

Espitalier-Noel, G., Adams, N.J. \& Klages, N.T. 1988. Diet of the Imperial Cormorant Phalacrocorax atriceps at sub-Antarctic Marion Island. Ети 88, 43-46.

Gales, R. 1998. Albatross populations: status and threats. In: Robertson, G. \& Gales, R. (Eds.). Albatross Biology and Conservation. Surrey Beatty \& Sons, Chipping Norton, pp. 20-45.

Gartshore, N.A., Cooper, J. \& Hunter, S. 1988b. Bird ringing at Marion and Prince Edwards Islands, 1982-1987; with an analysis of movements since 1951. South African Fournal of Antarctic Research 18, 23-29.

Gartshore, N.A., Steele, W.K. \& Klages, N.T. 1988a. Summer diet of the Salvin's Prion at sub-Antarctic Marion Island. South African Fournal of Zoology 23, 309-313.

Georges, J-Y. \& Guinet, C. 2000. Maternal care in the Subantarctic Fur Seals on Amsterdam Island. Ecology 8, 295-308.

Georges, J-Y., Tremblay, Y. \& Guinet, C. 2000. Seasonal diving behaviour in lactating Subantarctic Fur Seals on Amsterdam Island. Polar Biology 23, 59-69.
Goldsworthy, S.D. 1999. Maternal attendance behaviour of sympatrically breeding Antarctic and Subantarctic Fur Seals, Arctocephalus spp., at Macquarie Island. Polar Biology 21, 316-325.

Gon, O. \& Heemstra, P.C. 1990. Fishes of the Southern Ocean. J.L.B. Smith Institute of Ichthyology, Grahamstown.

González-Solís, J., Croxall, J.P. \& Wood, A.G. 2000. Foraging partitioning between giant petrels Macronectes spp. and its relationship with breeding population changes at Bird Island, South Georgia. Marine Ecology Progress Series 204, 279-288.

Green, K. \& Burton, H.R. 1993. Comparison of the stomach contents of the Southern Elephant Seal, Mirounga leonina, at Macquarie and Heard islands. Marine Mammal Science 9, 110-122.

Green, K., Williams, R. \& Green, M.G. 1998. Foraging ecology and diving behaviour of Macaroni Penguins Eudyptes chrysolophus at Heard Island. Marine Ornithology 26, 27-34.

Guinet, C., Jouventin, P. \& Weimerskirch, H. 1992. Population changes and movements of Southern Elephant Seals on Crozet and Kerguelen archipelagos in the last decades. Polar Biology 12, 349-356.

Guinet, C., Jouventin, P. \& Weimerskirch, H. 1999. Recent population change of the Southern Elephant Seals at Iles Crozet and Iles Kerguelen: the end of the decrease? Antarctic Science 11, 193-197.

Hall, K.J. \& Williams, A.J. 1981. Animals as agents of erosion at sub-Antarctic Marion Island. South African Fournal of Antarctic Research 10/11, 18-24.

Harper, P.C. 1983. Biology of the Buller's Shearwaters (Puffinus bulleri) at the Poor Knights Islands, New Zealand. Notornis 30, 299-318. 
Harper, P.C., Croxall, J.P. \& Cooper, J. 1985. A guide to foraging methods used by marine birds in Antarctic and Subantarctic seas. Biomass Handbook 24, 1-22.

Hilton, G.M., Thompson, D.R., Sagar, P.M., Cuthbert, R.J., Cherel, Y. \& Bury, S.J. 2006. A stable isotopic investigation into the causes of decline in a subAntarctic predator, the Rockhopper Penguin Eudyptes chrysocome. Global Change Biology 12, 61 1-625.

Hindell, M.A. (1991) Some life-history parameters of a declining population of Southern Elephant Seals, Mirounga leonina. Fournal of Animal Ecology 60, 119-134.

Hindell, M.A. \& Burton, H.R. (1987) Past and present status of the Southern Elephant Seal (Mirounga leonina) at Macquarie Island. Fournal of Zoology, London 213, 365-380.

Hockey, P.A.R., Dean, W.R.J. \& Ryan, P.G. (Eds.) 2005. Roberts' Birds of Southern Africa, 7th ed. John Voelcker Bird Book Fund, Cape Town.

Hoelzel, A.R., Halley, J., O’Brien, S.J., Campagna, C., Arnbom, T.R., Le Boeuf, B.J., et al. 1993. Elephant Seal genetic variation and the use of simulation models to investigate historical bottlenecks. Fournal of Heredity 84, 443-449.

Hofmeyr, G.J.G. 2000. Dispersal and dispersion of southern elephant seals at Marion Island. M.Sc. dissertation. University of Pretoria, South Africa.

Hofmeyr, G.J.G. \& Bester, M.N. 1993. Predation on King Penguins by Antarctic Fur Seals. South African Fournal of Antarctic Research 23, 71-74.

Hofmeyr, G.J.G., Bester, M.N. \& Jonker, FC. 1997. Changes in population sizes and distribution of fur seals at Marion Island. Polar Biology 17, 150-158.
Hofmeyr, G.J.G., Bester, M.N., Makhado, A.B. \& Pistorius, P.A. 2006. Population changes in Subantarctic and Antarctic Fur Seals at Marion Island. South African Fournal of Wildlife Research 36, 55-68.

Huin, N. 1994. Diving depths of Whitechinned Petrels. Condor 96, 1111-1113.

Hunter, S. 1983. The food and feeding ecology of the giant petrels Macronectes halli and M. giganteus at South Georgia. Journal of Zoology, London 200, 521-538.

Hunter, S. 1985. The role of giant petrels in the Southern Ocean ecosystem. In: Siegfried, W.R., Condy, P.R. \& Laws, R.M. (Eds.). Antarctic Nutrient Cycles and Food Webs. Springer, Berlin, pp. 534-542.

Hunter, S. 1988. The feeding ecology of avian predator-scavengers at Marion Island. In: Tasker, M.L. (Ed.). Seabird Food and Feeding Ecology. Proceedings of the 3rd International Conference of the Seabird Group. African Seabird Group, Cape Town, pp. 28-29.

Hunter, S. 1990. The impact of introduced cats on the predatorprey interactions of a sub-Antarctic avian community. In: Kerry, K.R. \& Hempel, G. (Eds.). Antarctic Ecosystems: Ecological Change and Conservation. Springer, Berlin, pp. 365-371.

Hunter, S. 1991. The impact of avian predator-scavengers on King Penguin Aptenodytes patagonicus chicks at Marion Island. Ibis 133, 343-350.

Hunter, S. \& Brooke, M. de L. 1992. The diet of giant petrels Macronectes spp. at Marion Island, southern Indian Ocean. Colonial Waterbirds 15, 56-65.

Hunter, S. \& Klages, N.T. 1989. The diet of Grey-headed Albatrosses Diomedea chrysostoma at the Prince Edward Islands. South African Fournal of Antarctic Research 19, 30-33. 
Huyser, O.A.W., Ryan, P.G. \& Cooper, J. 2000. Changes in population size, habitat use and breeding biology of Lesser Sheathbills at Marion Island: impacts of cats, mice and climate change? Biological Conservation 92, 299-310.

Jonker, F.C. \& Bester, M.N. 1994. The diving behaviour of Southern Elephant Seal, Mirounga leonina, cows from Marion Island. South African Fournal of Antarctic Research 24, 75-93.

Jonker, F.C. \& Bester, M.N. 1998. Seasonal movements and foraging areas of adult southern female Elephant Seals, Mirounga leonina, from Marion Island. Antarctic Science 10, 21-30.

Keith, M., Bester, M.N., Bartlett, P.A. \& Baker, D. 2001. Killer Whales (Orcinus orca) at Marion Island, Southern Ocean. African Zoology 36, 163-175.

Keith, D.G., Harck, B.I.B., Ryan, P.G. \& Mehlum, F. 2002. Post-breeding dispersal of Northern Giant Petrels Macronectes halli from Marion to Bouvet Islands. Marine Ornithology 30, 31.

Kerley, G.I.H. 1983a. Relative population sizes and trends, and hybridisation of fur seals Arctocephalus tropicalis and A. gazella at Prince Edward Islands, Southern Ocean. South African Fournal of Zoology 18, 388-392.

Kerley, G.I.H. 1983b. Record for the Cape Fur Seal Arctocephalus pusillus pusillus from sub-Antarctic Marion Island. South African Fournal of Zoology 18, 139-140.

Kerley, G.I.H. 1984. The relationship between two species of fur seals Arctocephalus tropicalis (Gray) and A. gazella (Peters) on Marion Island. M.Sc. Dissertation, University of Pretoria, South Africa.

Kerley, G.I.H. 1985. Pup growth in the fur seals Arctocephalus tropicalis and $A$. gazella on Marion Island. Fournal of Zoology, London 205, 315-324.
Kerley, G.I.H. 1987. Arctocephalus tropicalis on the Prince Edward Islands. In: Groxall, J.P. \& Gentry, R.L. (Eds.). Status, Biology, and Ecology of Fur Seals. NOAA Technical Publication Report NMFS 51, 61-64.

King, J. 1959. The northern and southern populations of Arctocephalus gazella. Mammalia 23, 19-40.

Kirkman, S.P., Bester, M.N., Hofmeyr, G.J.G., Jonker, F.G., Pistorius, P.A., Owen, R., et al. 2004. Variation in the timing of the breeding haulout of female Southern Elephant Seals at Marion Island. Australian fournal of Zoology 52, 379-388.

Kirkman, S.P., Bester, M.N., Hofmeyr, G.J.G., Pistorius, P.A. \& Makhado, A.B. 2002. Pup growth and maternal attendance patterns in Subantarctic Fur Seals. African Zoology 37, 13-19.

Kirkman, S.P., Bester, M.N., Makhado, A.B. \& Pistorius, P.A. 2003. Female attendance patterns of Antarctic Fur Seals at Marion Island. African Zoology 38, 402-405.

Kirkman, S.P., Bester, M.N., Pistorius, P.A., Hofmeyr, G.J.G., Owen, R. \& Mecenero, S. 2001. Participation in the winter haulout by Southern Elephant Seals, Mirounga leonina. Antarctic Science 13, 380-384.

Klages, N.T.W. \& Bester, M.N. 1998. The fish prey of Fur Seals Arctocephalus spp. at subantarctic Marion Island. Marine Biology 131, 559-566.

Klages, N.T.W., Nel, D.C. \& Cooper, J. 1995. Stomach contents of a Greybacked Storm Petrel from Subantarctic Marion Island. Marine Ornithology 23, 163-164.

Kuroda, N. 1954. On the Classification and Phylogeny of the Order Tubinares, particularly the Shearwaters (Puffinus). Author, Tokyo. 
La Cock, G.D., Hecht, T. \& Klages, N.T. 1984. The winter diet of Gentoo Penguins at Marion Island. Ostrich 55, 188-191.

La Grange, J.J. 1962. Notes on the birds and mammals on Marion Island and Antarctica (S.A.N.A.E.) Fournal of the South African Biological Society 3, 27-84.

Laws, R.M. 1956. The Elephant Seal (Mirounga leonina Linn.). II. General, social and reproductive behaviour. Falkland Islands Dependencies Survey Scientific Reports 13, 1-88.

Laws, R.M. 1993. Identification of species. In: Laws R.M. (Ed.). Antarctic Seals: Research Methods and Techniques. Cambridge University Press, Cambridge, England, pp. 1-28.

Lea, M.A., Guinet, C., Cherel, Y., Duhamel, G., Dubroca, L., Pruvost, P., et al. 2006. Impacts of climatic anomalies on provisioning strategies of a Southern Ocean predator. Marine Ecology Progress Series 310, 77-94.

Makhado, A.B. 2002. The diet of fur seals (Arctocephalus tropicalis and A. gazella) at Marion Island. M.Sc. Dissertation, University of Pretoria, South Africa.

Malherbe, J. 1998. The diving behaviour of Southern Elephant Seal, Mirounga leonina, bulls. M.Sc. Dissertation, University of Pretoria, South Africa.

Marchant, S. \& Higgins, P.J. (Eds.) 1990. Handbook of Australian, New Zealand $\mathcal{E}^{\circ}$ Antarctic Birds, Vol. 1: Ratites to Ducks. Oxford University Press, Melbourne.

Marchant, S. \& Higgins, P.J. (Eds.). 1993. Handbook of Australian, New Zealand E Antarctic Birds, Vol. 2: Raptors to Lapwings. Oxford University Press, Melbourne.
McCafferty, D.J., Boyd, I.L., Walker, T.R. \& Taylor, R.I. 1998. Foraging responses of Antarctic Fur Seals to changes in the marine environment. Marine Ecology Progress Series 166, 285-299.

McMahon, G.R., Bester, M.N., Burton, H.R., Hindell, M.A. \& Bradshaw, C.J.A. 2005. Population status, trends and a re-examination of the hypotheses explaining the recent declines of the southern elephant seal Mirounga leonina. Mammal Review 35, 82-100.

McMahon, C.R., Burton, H.R. \& Bester, M.N. 2003. A demographic comparison of two Southern Elephant Seal populations. Fournal of Animal Ecology 72, 61-74.

McQuaid, C.D. \& Fronemann, P.W. 2008. Biology in the oceanographic environment. In: Chown, S.L. \& Froneman, P.W. (Eds.). The Prince Edward Islands. Land-Sea Interactions in a Changing Ecosystem. African Sun Media, Stellenbosch, pp. 97-120.

Mills, M.S.L. \& Ryan, P.G. 2005. Modelling impacts of long-line fishing: what are the effects of pair-bond disruption and sex-biased mortality on albatross fecundity? Animal Conservation 8, 359-367.

Nel, D.C., Lutjeharms J.R.E., Pakhomov, E.A., Ansorge, I.J., Ryan, P.G. \& Klages, N.T.W. 2001. Exploitation of mesoscale oceanographic features by Grey-headed Albatrosses Thalassarche chrysostoma in the southern Indian Ocean. Marine Ecology Progress Series 217, 15-26.

Nel, D.C. \& Nel, J.L. 1999. Marine debris and fishing gear associated with seabirds at sub-Antarctic Marion Island, 1996/97 and 1997/98 in relation to longline fishing activity. CCAMLR Science 6, 85-96. 
Nel, D.C., Nel, J.L., Ryan, P.G., Klages, N.T.W., Wilson, R.P. \& Robertson, G. 2000. The foraging ecology of Greyheaded Mollymawks at Marion Island, southern Indian Ocean, in relation to known longline fishing activity. Biological Conservation 96, 219-231.

Nel, D.C., Ryan, P.G., Crawford, R.J.M., Cooper, J. \& Huyser, O.A.W. 2002c. Population trends of albatrosses and petrels breeding at sub-Antarctic Marion Island. Polar Biology 25, 81-89.

Nel, D.C., Ryan, P.G., Nel, J.L., Klages, N.T.W., Wilson, R.P., Robertson, G., et al. 2002a. Foraging interactions between Wandering Albatrosses Diomedea exulans breeding on Marion Island and long-line fisheries in the southern Indian Ocean. Ibis 144, E141-E154.

Nel, D.C., Ryan, P.G. \& Watkins, B.P. 2002b. Seabird mortality in the Patagonian toothfish longline fishery around the Prince Edward Islands, 1996-2000. Antarctic Science 14, 151-161.

Nel, D.C., Taylor, F., Ryan, P.G. \& Cooper, J. 2003. Population dynamics of Wandering Albatrosses Diomedea exulans at sub-Antarctic Marion Island: long-line fishing and environmental influences. African Fournal of Marine Science 25, 503-517.

Newton, I.P. \& Fugler, S.R. 1989. Notes on the winter-breeding Greatwinged Petrel Pterodroma macroptera and Grey Petrel Procellaria cinerea at Marion Island. Cormorant 17, 27-34.

Osbourne, R.F., Naidoo, A.D. \& Verheye, H.M. (Eds.) 2002. Research Highlights 2001-2002. Marine \& Coastal Management, Cape Town.

Panagis, K. 1984. The influence of Southern elephant Seals Mirounga leonina (Linnaeus) on the coastal terrestrial ecology of Marion Island. M.Sc. Thesis, University of Pretoria, South Africa.
Payne, M.R. 1979. Growth in the Antarctic Fur Seal Arctocephalus gazella. Fournal of Zoology, London 187, 1-20.

Perissinotto, R. \& Duncombe Rae, C.M. 1990. Occurrence of anticyclonic eddies on the Prince Edward Plateau (Southern Ocean): effects on phytoplankton biomass and production. Deep-Sea Research 37, 777-793.

Pistorius, P.A. \& Bester, M.N. 2002. Juvenile survival and population regulation in Southern Elephant Seals at Marion Island. African Zoology 37, 35-41.

Pistorius, P.A., Bester, M.N. \& Kirkman, S.P. 1999a. Dynamic age-distributions in a declining population of Southern Elephant Seals. Antarctic Science 11, 446-451.

Pistorius, P.A., Bester, M.N. \& Kirkman, S.P. 1999b. Survivorship of a declining population of Southern Elephant Seals, Mirounga leonina, in relation to age, sex and cohort. Oecologia 121, 201-211.

Pistorius, P.A., Bester, M.N., Kirkman, S.P. \& Taylor, F.E. 2001. Pup mortality in Southern Elephant Seals at Marion Island. Polar Biology 24, 828-831.

Pistorius, P.A., Bester, M.N., Lewis, M.N., Taylor, F.E., Campagna, C. \& Kirkman, S.P. 2004. Adult female survival, population trend, and the implications of early primiparity in a capital breeder, the Southern Elephant Seal (Mirounga leonina). Fournal of Zoology, London 263, 107-119.

Pistorius, P.A., Taylor, F.E., Louw, C., Hanise, B., Bester, M.N., de Wet, C., et al. 2002. Distribution, movement, and estimated population size of Killer Whales (Orcinus orca) at Marion Island, December 2000. South African Journal of Wildife Research 32, 86-92. 
Prince, P.A., Croxall, J.P., Trathan, P.N. \& Wood, A.G. 1998. The pelagic distribution of South Georgia albatrosses and their relationships with fisheries. In: Robertson, G. \& Gales, R. (Eds.). Albatross Biology and Conservation. Surrey Beatty \& Sons, Chipping Norton, pp. 137-167.

Prince, P.A., Huin, N. \& Weimerskirch, H. 1994. Diving depths of albatrosses. Antarctic Science 6, 353-354.

Prince, P.A. \& Jones, M. 1992. Maximum dive depths attained by South Georgian Diving Petrel Pelecanoides georgicus at Bird Island, South Georgia. Antarctic Science 4, 433-434.

Pütz, K. 2002. Spatial and temporal variability in the foraging areas of breeding King Penguins. Condor 104, 528-538.

Pütz, K., Wilson, R.P., Charrassin, J.-B., Raclot, T., Lage, J., le Maho, Y., et al. 1998. Foraging strategy of King Penguins (Aptenodytes patagonicus) during summer at the Crozet Islands. Ecology 79, 905-1921.

Quintana, F. \& Dell'Arciprete, O.P. 2002. Foraging grounds of Southern Giant Petrels (Macronectes giganteus) on the Patagonian Shelf. Polar Biology 25, 159-161.

Rand, R.W. 1954. Notes on the birds of Marion Island. Ibis 96, 173-206.

Rand, R.W. 1956. Notes on the Marion Island fur seal. Proceedings of the Royal Society of London 126, 65-82.

Rand, R.W. 1963. Seabirds in the southern Indian Ocean. Ostrich 34, 121-128.

Richards, R. 1992. The commercial exploitation of sea mammals at Iles Crozet and the Prince Edward Islands before 1850. Polar Monographs 1, 1-19.
Ridoux, V. 1994. The diets and dietary segregation of seabirds at the Subantarctic Crozet Islands. Marine Ornithology 22, 1-192.

Robinson, S.A., Goldsworthy, S.G., Van den Hoff, J. \& Hindell, M.A. 2002. The foraging ecology of two sympatric fur seal species, Arctocephalus gazella and Arctocephalus tropicalis, at Macquarie Island during the austral summer. Marine and Freshwater Research 53, 1071-1082.

Ryan, P.G. 1987a. The incidence and characteristics of plastic particles ingested by seabirds. Marine Environmental Research 23, 175-206.

Ryan, P.G. 1987b. The distribution, population size and foraging behaviour of Kerguelen Terns at the Prince Edward Islands. South African Fournal of Antartic Research 17, 163-166.

Ryan, P.G. 2002. More than an island fling? Attempted rapes by Wandering Albatrosses. Africa Birds \& Birding 7, 15.

Ryan, P.G., Avery, G., Rose, B., Ross, G.J.B., Sinclair, J.C. \& Vernon, C.J. 1989. The Southern Ocean seabird irruption to South African waters during winter 1984. Cormorant 17, 41-55.

Ryan, P.G. \& Boix-Hinzen, C. 1999. Consistent male-biased seabird mortality in the Patagonian Toothfish long-line fishery. Auk 116, 851-854.

Ryan, P.G., Cooper, J., Dyer, B.M., Underhill, L.G., Crawford, R.J.M. \& Bester, M.N. 2003a. Counts of surface-nesting seabirds breeding at sub-Antarctic Prince Edward Island, summer 2001/02. African Fournal of Marine Science 25, 441-451.

Ryan, P.G. \& Hunter, S. 1985. Early breeding of Imperial Cormorants at Prince Edward Island. Cormorant 13, 31-34. 
Ryan, P.G. \& Jackson, S. 1986. Stomach pumping: is killing seabirds necessary? Auk 103, 427-428.

Ryan, P.G. \& Jackson, S. 1987. The lifespan of ingested plastic particles in seabirds and their effect on digestive efficiency. Marine Pollution Bulletin 18, 217-219.

Ryan, P.G., Keith, D.G. \& Kroese, M. 2002. Seabird bycatch by tuna longline fisheries off southern Africa. South African Fournal of Marine Science 24, 103-110.

Ryan, P.G., Smith, V.R. \& Gremmen, N.J.M. 2003b. The distribution and spread of alien vascular plants on Prince Edward Island. African fournal of Marine Science 25, 555-561.

SCAR EGS 2004. Scientific Committee for Antarctic Research - Expert Group on Seals Report: http:/www. fagmed.uit.no/info/imb/aab/Scar/ pdf/statusofstocs.pdf

Schramm, M. 1983. The breeding biologies of the petrels Pterodroma macroptera, P. brevirostris and $P$. mollis at Marion Island. Етu 83, 75-81.

Schramm, M. 1986. The diet of chicks of Greatwinged, Kerguelen and Softplumaged Petrels at the Prince Edward Islands. Ostrich 57, 9-15.

Shaffer, S.A., Costa, D.P. \& Weimerskirch, H. 2003. Foraging effort in relation to the constraints of reproduction in free-ranging albatrosses. Functional Ecology 17, 66-74.

Siegfried, W.R., Williams, A.J., Burger, A.E. \& Berruti, A. 1978. Mineral and energy contributions of eggs of selected species of birds to the Marion Island terrestrial ecosystem. South African Fournal of Antarctic Research 8, 75-87.
Skinner, J.D. \& Smithers, R.H.N. 1990. The Mammals of the Southern African Subregion. University of Pretoria, Pretoria.

Slade, R.W. 1997. Genetic studies of the Southern Elephant Seal, Mirounga leonina. In: Hindell, M. \& Kemper, C. (Eds.). Marine Mammal Research in the Southern Hemisphere. Vol. 1: Status, Ecology and Medicine. Surrey Beatty and Sons, Chipping Norton, pp. 11-29.

Slip, D.J. 1995. The diet of Southern Elephant Seals (Mirounga leonina) at Heard Island. Canadian Fournal of Zoology, 73, 1519-1528.

Smith, V.R \& Froneman, P.W. 2008. Nutrient dynamics in the vicinity of the Prince Edward Islands. In: Chown, S.L. \& Froneman, P.W. (Eds.). The Prince Edward Islands. Land-Sea Interactions in a Changing Ecosystem. African Sun Media, Stellenbosch, pp. 165-179.

Steele, W.K. \& Klages, N.T. 1986. Diet of the Blue Petrel at sub-Antarctic Marion Island. South African Fournal of Zoology 21, 253-256.

Tickell, W.L.N. 2000. Albatrosses. Pica Press, Sussex.

Tremblay, Y. \& Cherel, Y. 2000. Benthic and pelagic dives: a new foraging behaviour in Rockhopper Penguins. Marine Ecology Progress Series 204, 257-267.

Underhill, L.G., Petersen, S.L. \& Cooper, J. 2003. Nest densities of the Wandering Albatross Diomedea exulans at the Prince Edward Islands, estimated using GPS. African fournal of Marine Science 25, 529-535.

Van Aarde, R.J. 1980. The diet and feeding behaviour of feral cats, Felis catus at Marion Island. South African fournal of Wildlife Research 10, 123-128. 
Van den Hoff, J., Burton, H. \& Davies, R. 2003. Diet of male Southern Elephant Seals (Mirounga leonina L.) hauled out at Vincennes Bay, East Antarctica. Polar Biology 26, 27-31.

Van Heezik, Y.M., Seddon, P.J. \& Cooper, J. 1995. Effects of interannual and inter-colony variability on counts of King Penguin colonies on Marion Island. In: Dann, P., Norman, I. \& Reilly, P. (Eds.). The Penguins: Ecology and Management. Surrey Beatty \& Sons, Chipping Norton, pp. 96-110.

Van Heezik, Y.M., Seddon, P.J., Cooper, J. \& Plös, A.L. 1994. Interrelationships between breeding frequency, timing and outcome in King Penguins Aptenodytes patagonicus: are King Penguins biennial breeders? Ibis 136, 279-284.

Van Heezik, Y.M., Seddon, P.J., du Plessis, C.J. \& Adams, N.J. 1993. Differential growth of King Penguin chicks in relation to date of hatching. Colonial Waterbirds 16, 71-76.

Van Rensburg, P.J.J. \& Bester, M.N. 1988. The effect of cat Felis catus predation on three Procellariidae species on Marion Island. South African Fournal of Zoology 23, 301-305.

Walker, T.R., Boyd, I.L., McCafferty, D.J., Huin, N., Taylor, R.I. \& Reid, K. 1998. Seasonal occurrence and diet of Leopard Seals (Hydrurga leptonyx) at Bird Island, South Georgia. Antarctic Science 10, 75-81.

Warham, J. 1990. The Petrels, their Ecology and Breeding Systems. Academic Press, London.

Watkins, B.P. 2000. Killer Whale group attacks Sperm Whales. African Environment and Wildlife 8, 16-17.

Watkins, B.P. \& Cooper, J. 1986. Introduction, present status and control of alien species at the Prince Edward Islands, sub-Antarctic. South African Fournal of Antarctic Research 16, 86-94.
Weimerskirch, H. 1992. Reproductive effort in long-lived birds: age-specific patterns of condition, reproduction and survival in the Wandering Albatross. Oikos 64, 464-473.

Weimerskirch, H. 1998. Foraging strategies of Indian Ocean albatrosses and their relationships with fisheries. In: Robertson, G. \& Gales, R. (Eds.). Albatross Biology and Conservation. Surrey Beatty \& Sons, Chipping Norton, pp. 168-179.

Weimerskirch, H. 2004. Diseases threaten Southern Ocean albatrosses. Polar Biology 27, 374-379.

Weimerskirch, H., Bonadonna, F., Bailleul, F., Mabille, G., Dell'Omo, G. \& Lipp. H.-P. 2002. GPS tracking of foraging albatrosses. Science 295, 1259.

Weimerskirch, H., Catard, A., Prince, P.A., Cherel, Y. \& Croxall, J.P. 1999. Foraging White-chinned Petrels Procellaria aequinoctialis: at risk from the tropics to Antarctica. Biological Conservation 87, 273-275.

Weimerskirch, H., Chastel, O., Ackermann, L., Chaurand, T., Cuenot-Chaillet, F., Hindermeyer, X., et al. 1994b. Alternate long and short foraging trips in pelagic-seabird parents. Animal Behaviour 47, 472-476.

Weimerskirch, H., Doncaster, C.P. \& Cuenot-Chaillet, F. 1994a. Pelagic seabirds and the marine environment: foraging patterns of Wandering Albatrosses in relation to prey availability and distribution. Proceedings of the Royal Society of London B 255, 91-97.

Weimerskirch, H., Guionnet, T., Martin, J., Shaffer, S.A. \& Costa, D.P. 2000. Fast and fuel efficient? Optimal use of wind by flying albatrosses. Proceedings of the Royal Society of London B 267, 1869-1874. 
Weimerskirch, H. \& Jouventin, P. 1998. Changes in population size and demographic parameters of six albatross species breeding in the French sub-Antarctic islands. In: Robertson, G. \& Gales, R. (Eds.). Albatross Biology and Conservation. Surrey Beatty \& Sons, Chipping Norton, pp. 84-91.

Weimerskirch, H. \& Robertson, G. 1994. Satellite tracking of Light-mantled Sooty Albatross. Polar Biology 14, 123-126.

Weimerskirch, H., Stahl, J.-C. \& Jouventin, P. 1992. The breeding biology and population dynamics of King Penguins Aptenodytes patagonicus on the Crozet Islands. Ibis 134, 107-117.

Wilkinson, I.S. 1992. Factors affecting reproductive success of Southern Elephant Seals, Mirounga leonina, at Marion Island. Ph.D. Thesis, University of Pretoria, South Africa.

Wilkinson, I.S. \& Bester, M.N. 1990. Continued population increase in fur seals, Arctocephalus tropicalis and A. gazella, at the Prince Edward Islands. South African Fournal of Antarctic Research 20, 58-63.

Williams, A.J. 1980. Aspects of the breeding biology of Gentoo Penguins, Pygoscelis papua. Gerfaut 70, 283-295.

Williams, A.J. \& Berruti, A. 1978. Mineral and energy contributions of feathers moulted by penguins, gulls and cormorants to the Marion Island terrestrial ecosystem. South African Journal of Antarctic Research 8, 71-74.
Williams, T.D. 1995. The Penguins Spheniscidae. Oxford University Press, Oxford.

Wilson, R.P. 1984. An improved stomach pump for penguins and other seabirds. Fournal of Field Ornithology 55, 109-112.

Wilson, R.P., Bost, G.-A., Pütz, K., Charrassin, J.-B., Culik, B.M. \& Adelung, D. 1997. Southern Rockhopper Penguin Eudyptes chrysocome chrysocome foraging at Possession Island. Polar Biology 17, 323-329.

Wilson, R.P., Grémillet, D., Syder, J., Kierspel, M.A.M., Garthe, S., Weimerskirch, H., et al. 2002. Remotesensing systems and seabirds: their use, abuse and potential for measuring marine environmental variables. Marine Ecology Progress Series 228, 241-261.

Wilson, R.P., Hustler, K., Ryan, P.G., Burger, A.E. \& Nöldeke, E.C. 1992. Diving birds in cold water: do Archimedes and Boyle determine energetic costs? American Naturalist 140, 179-200.

Woehler, E.J. 1993. The Distribution and Abundance of Antarctic and sub-Antarctic penguins. SCAR, Cambridge.

Wynen, L.P., Goldsworthy, S.D., Guinet, G., Bester, M.N., Boyd, I.L., Gjertz, I., et al. 2000. Post-sealing genetic variation and population structure of two species of fur seal (Arctocephalus gazella and $A$. tropicalis). Molecular Ecology 9, 299-314. 